ROCZNIKI TEOLOGICZNE

Tom LXVII, zeszyt 3 - 2020

DOI: https://doi.org/10.18290/rt.20673-5

\author{
BP JÓZEF WRÓBEL SCJ
}

\title{
BIOETYCZNY I TEOLOGICZNOMORALNY WYMIAR ZAMRAŻANIA LUDZKICH EMBRIONÓW
}

\author{
THE BIOETHICAL AND MORAL THEOLOGY DIMENSION \\ OF HUMAN EMBRYO CRYOPRESERVATION
}

\begin{abstract}
The article discusses the issues of cryopreservation of human embryos. The use of this technique is related to assisted procreation. The supernumerary embryos created in order to increase the effectiveness of the in vitro procedure are frozen so that they can be used in subsequent transfer attempts. The author presents the technical dimension of freezing and the risks associated with it. In the last part, the author analyzes the ethical dimension of these techniques. He emphasize that although assisted procreation is immoral itself, it is morally right to strive to correct this evil by the mother, who is ready to accept into her womb the thawed embryos. The adoption of abandoned embryos seems to be a good solution. However, this solution cannot be justified from the ethical point of view. If it is forced by law to defrost or terminate the contract by the clinic that stores the embryos, it is possible to consent to their death. The health condition of the embryos, which makes their development impossible, releases from the obligation to transfer. Moreover, it is immoral to select embryos by eugenics and transfer only those embryos that have the desired phenotypic or sex characteristics.
\end{abstract}

Key words: cryopreservation of embryos; ART; assisted procreation.

Rozwój medycyny stał się możliwy dzięki rozwojowi szeregu nauk pomocniczych, w tym nauk technicznych. Już od III wieku chrześcijaństwo pozytywnie ocenia takie przymierze. Jednakże związek ten nie jest wolny od zagrożeń. Ich głównym źródłem jest pozytywizm scjentystyczny, czyli tendencja do oceniania wartości techniki wyłącznie z perspektywy możliwych jej aplika-

Bp dr hab. JózeF WróBEL SCJ, prof. KUL - Katedra Bioetyki Teologicznej, Instytut Nauk Teologicznych, Katolicki Uniwersytet Lubelski Jana Pawła II; adres do korespondencji: ul. S. Kard. Wyszyńskiego 2, 20-105 Lublin; e-mail: jozef.wrobel@kul.pl; ORCID:https//org/ 0000-0003-4254-3065. 
cji, stwarzanych przez nią możliwości oraz jej niezawodności. Integralna ocena techniki domaga się jednak uwzględnienia nadawanej jej przez człowieka celowości. Może ona bowiem służyć jego poznaniu i usprawnieniu działania, ułatwiając w ten sposób realizację jego zamierzeń. Tym samym staje się narzędziem służącym osiągnięciu przez niego celów dobrych lub złych; może służyć praktyce miłości lub destrukcji człowieka ${ }^{1}$.

Ambiwalentna wartość techniki ujawnia się w szczególny sposób w medycynie początków ludzkiego życia. Niejednokrotnie staje się ona tutaj narzędziem służącym badaniu i leczeniu embrionów oraz płodów, ale równie często $\mathrm{w}$ sztucznej prokreacji, w eksperymentach $\mathrm{i} \mathrm{w}$ manipulacjach staje się środkiem ich niszczenia i uprzedmiotowienia. Tymi ostatnimi skutkami owocują szczególnie techniki związane z zamrażaniem ludzkich embrionów.

Praktyka zamrażania organicznych tkanek (zasadniczo utrwalania żywności) jest stosowana od dawna ${ }^{2}$. We współczesnych czasach technologie schładzania i zamrażania, bazujące na ciekłym lub zestalonym dwutlenku węgla (od dawna wykorzystywanym także w medycynie) oraz w różnych chemicznych mieszankach, są masowo stosowane od 1930 roku. We współczesnych laboratoriach wykorzystuje się w tych celach głównie wspomniany zestalony dwutlenek węgla $\left(-78,5^{0}\right)$ oraz ciekły azot $\left(-196^{0}\right)$.

Pierwsze eksperymenty z kriokonserwacją gamet prowadził ze swoimi współpracownikami od 1949 r. angielski biolog z Cambridge, założyciel Society for Cryobiology, Ernest John Christopher Polge (1926-2006) ${ }^{3}$. W doświadczeniach korzystał on z krioprotektantów, które zostały odkryte w owadach przeżywających okres zimowy w głębokim schodzeniu. Substancje te chronią komórki przed tworzeniem się w nich kryształków lodu niszczących ich delikatną strukturę. Dzięki krioprotektantom w procesie zamrażania płyn komórkowy przyjmuje postać amorficzną. W efekcie tych doświadczeń

${ }^{1}$ Por. Katechizm Kościoła Katolickiego: „Nauka i technika są cennymi pomocami, gdy służą człowiekowi i jego integralnemu rozwojowi dla dobra wszystkich; nie mogą jednak same ustalać sensu istnienia i postępu ludzkiego. Nauka i technika są podporządkowane człowiekowi, od którego biorą początek i rozwój; zatem w osobie i w jej wartościach moralnych znajdują one swoją celowość i świadomość swoich ograniczeń" (wyd. 2, Poznań 2002, nr 2293). Por. także S. RosıK, Techniki manipulacyjne w aspekcie wymagań moralnych, „Roczniki Teologiczno-Kanoniczne" 25(1978), z. 3, s. 33; J. WRÓBEL, Człowiek i medycyna. Teologicznomoralne podstawy ingerencji medycznych, Kraków 1999, s. 126-134.

${ }^{2}$ Wystarczy przypomnieć obecność w dawnych zamkach i dworach izolowanych spiżarni, w których nawet w lecie między zwałami zgromadzonego w zimie lodu przechowywano żywność, chroniąc ją przed zepsuciem.

${ }^{3}$ W 1949 roku ukazał się pod jego kierunkiem w „Nature” pierwszy artykuł na temat zamrażania plemników: C. Polge, A.U. SMITH, A.S. PARKES, Revival of spermatozoa after vitrification and dehydration at low temperatures, „Nature” 164(1949), s. 666-667. 
w 1954 r. na świat przyszły pierwsze dzieci poczęte z zamrożonych plemników ${ }^{4}$. Mrożenie komórek jajowych, chociaż możliwe, jest w Polsce prawnie ograniczone. Dozwolone jest ono tylko ze wskazania medycznego, kiedy w wyniku agresywnej terapii kobieta nie mogłyby już więcej zajść w ciążę.

Z kolei technika zamrażania ludzkich embrionów jest stosowana od początków lat siedemdziesiątych XX wieku. Szczególnie dynamicznie rozwijała się od połowy lat osiemdziesiątych. Natomiast 28 marca 1984 r. w Melbourne, w Australii, przyszła na świat Zoe Leyland, pierwsze dziecko, które było zamrożone na etapie embrionalnym ${ }^{5}$. W Polsce biotechnologię tę jako pierwsza zastosowała klinika Akademii Medycznej w Białymstoku. Jednak pierwsze dzieci z zamrożonych embrionów przyszły na świat w warszawskiej Przychodni Leczenia Niepłodności „nOvum” w lipcu 1997 roku. Do 2013 r. technologia ta została wykorzystana w tej klinice w przypadku 2,4 tys. dzieci ${ }^{6}$.

\section{PERSPEKTYWA ANTROPOLOGICZNA PRAKTYKI IN VITRO I ZAMRAŻANIA LUDZKICH EMBRIONÓW}

Bioetyka (bios + ethos) jako nauka funkcjonuje w wymiarze teoretycznym i praktycznym. Pierwszy wymiar opiera się na przesłankach antropologii filozoficznej i wypracowuje zasady etyczne postępowania w obrębie praktyk medycznych i biomedycznych ${ }^{7}$. Pełniąc taką rolę, tworzy ona też modele postępowania w oparciu o określony system wartości ${ }^{8}$.

${ }^{4}$ Początkowo E.J.Ch. Polge zajmował się z pozytywnym rezultatem zamrażania tkanek wykorzystywanych w transplantacjach (por. W.R. RALL, Ernest John Christopher Polge FRS (19262006), „Cryobiology” 54(2007), nr 3, s. 241-242. Por. także A. NiwińsKA, Przeglad metod kriokonserwacji pod katem techniki witryfikacyjnej, „Życie Weterynaryjne” 2016, nr 7(91), s. 505.

${ }^{5}$ Por. J. LEETON. The early history of IVF in Australia and its contribution to the World (1970B1990), „Australian and New Zealand Journal of Obstetrics and Gynaecology”44(2004), nr 6, s. 495-501. Według innego źródła narodziny pierwszego dziecka z zamrożonego embrionu ogłoszono już w 1983 roku (por. R. RigGS, J. MAYER, D. Dowling-LaCEY, T.-F. CHI, E. JONES, S. OEHNINGER, Does storage time in uence postthaw survival and pregnancy outcome? An analysis of 11,768 cryopreserved human embryos, „Fertility and Sterility” 93(2010), nr 1, s. 109.

${ }^{6}$ Por. K. PaPIS, P. LeWANdowski, J.K. Wolski, K. KozIOŁ, Dzieci urodzone z zarodków przechowywanych $w$ stanie zamrożenia przez 10 lat. Analiza 5 przypadków, „Ginekologia Polska” 2013, nr 11(84), s. 971.

${ }^{7}$ T. Biesaga definiuje bioetykę jako: ,wyspecjalizowana część filozoficznej etyki szczegółowej, ustalająca oceny i normy moralne w stosunku do ingerencji w życie ludzkie w granicznych sytuacjach jego powstawania (biogeneza), trwania (bioterapia) i śmierci (tanatologia)" (Bioetyka, w: Encyklopedia bioetyki. Personalizm chrześcijański. Gtos Kościoła, red. A. Muszala, Radom 2005, s. 54-55).

${ }^{8}$ Por. E. Sgreccia, Manuale di bioetica, t. 1: Fondamenti e etica biomedica, wyd. 4, 
Bioetyka inspiracji katolickiej opiera się na przesłankach antropologii personalistycznej i teologicznej. W tym ujęciu fundament refleksji etycznej stanowi duchowo-cielesna natura człowieka stworzonego przez Boga. Oznacza to, że autonomiczna wizja biologiczno-fizjologiczna, a z drugiej strony sama wizja czysto duchowa nie wyczerpują prawdy o nim. Człowiek, widziany integralnie, jest istotą duchowo-cielesną. Taka natura człowieka ma istotne znaczenie dla refleksji bioetycznej. Dzięki substancjalnemu zjednoczeniu „ciało ludzkie nie może być uważane tylko za zespół tkanek, narządów i funkcji; nie może być oceniane na równi z ciałem zwierząt, jest bowiem częścią istotną osoby, która poprzez to ciało objawia się i wyraża"9.

Jako nauka praktyczna, bioetyka ma na celu ocenę konkretnego postępowania medycznego i biomedycznego w obszarze związanym z procesami ludzkiego zdrowia i życia (od poczęcia do naturalnej śmierci). Podstawowym punktem odniesienia tej oceny jest przedstawiony wyżej fundament antropologiczny. Prowadzi on do konkluzji, że ,interwencja dokonywana na ciele ludzkim nie dotyczy tylko tkanek, narządów i ich funkcji, lecz angażuje również na różnych poziomach samą osobę"10. Takie odniesienie ingerencji biomedycznych - do osoby, a nie tylko do jej elementów biologiczno-fizjologicznych - wynika z zasięgu jej osobowej godności, w której w jednakowej mierze uczestniczy dusza i ciało.

Godność osobowa człowieka nie może być ujmowana tylko w wymiarach naturalnych jako jakieś uprzywilejowane miejsce człowieka pośród świata istot żywych. W ujęciu antropologii teologicznej ma ona na uwadze prawdę o człowieku jako stworzonym na obraz i podobieństwo Boże. Stwierdzenie to nie ma na myśli tylko opisu stworzenia pierwszych ludzi w Księdze Rodzaju (por. Rdz 1,26-27). Ma ono na względzie także oparte na przesłankach biblijnych nauczanie Kościoła na temat pochodzenia duszy każdego człowieka. Uczy on bowiem, że „Bóg stwarza z niczego (ex nihilo) każdą duszę i łączy ją jednocześnie z rodzicielskimi komórkami w akcie prokreacji, powołując człowieka do istnienia w jego osobowej jedności"11.

Milano 2007, s. 55-99; M. CHIODI, Modelli teoretici in bioetica, Milano 2005; R. PASCUAL, Modelli di bioetica, Roma 2007; T.L. BEAUChAmP, J.F. ChILDRESs, Zasady etyki medycznej, Warszawa 1996, s. 53-130.

${ }^{9}$ KONGREGACJA NAUKI WIARY, Instrukcja o szacunku dla rodzqcego się życia ludzkiego i o godności jego przekazywania „Donum vitae”, Rzym 1987, Wstęp 3.

${ }^{10}$ Tamże.

${ }^{11}$ Por. K.T. Wencel, Traktat o człowieku, w: Dogmatyka, t. 5, red. E. Adamiak, A. Czaja, J. Majewski, Warszawa 2007, s. 88; por. LEON X, Bulla „Apostolici regiminis: De anima humana doctrina contra Neo-Aristotelicos", Rzym 1513, w: Enchiridion symbolorum definiotionum et declarationum de rebus fidei et morum, red. H. Denzinger, Bologna 1995, nr 14401441; Aleksander VII, Breve „Sollicitudo omnium ecclesiarum: De immaculata conceptione 
Powyższe odniesienie rzuca też światło na naturę ludzkiej prokreacji. Chociaż można wyliczyć pewne podobieństwa między przekazywaniem życia przez ludzkich rodziców i rozmnażaniem się ssaków, to jednak w spojrzeniu integralnym między tymi procesami zachodzi istotna różnica. Proces rozmnażania się zwierząt wyczerpuje się na poziomie biologiczno-fizjologicznym jako realizacja właściwego im instynktu. W przypadku ludzkiej prokreacji proces ten istotnie wykracza poza te granice i stwarza przestrzeń dla podkreślonego wyżej zaangażowania się samego Boga Stwórcy w genezę każdego człowieka. Efektem Jego uczestnictwa nie jest samo w sobie przyjście na świat członka gatunku homo sapiens, ale „zrodzenie osoby"12.

Filozoficzny i teologiczny fundament niezbywalnej godności każdego człowieka i ludzkiej prokreacji Kościół uzupełnia o przesłanki płynące z nauk biologicznych i medycznych. Jakkolwiek naukom tym jest metodologicznie obcy problem animacji ludzkiego zarodka, to jednak mogą się one kompetentnie wypowiadać na temat procesów ludzkiej ontogenezy, która w powszechnym nauczaniu embriologii zaczyna się od fuzji gamet rodziców i procesu zapłodnienia. W jego efekcie „dwa haploidalne komplety chromosomów (chromatyny) przystępują do tworzenia przedjądrzy [...]. [One z kolei] rozpoczynają syntezę DNA, a po replikacji DNA [...] przemieszczają się do środka komórki jajowej. Około 20 godzin po zapłodnieniu następuje kondensacja chromosomów. Przedjądrza zbliżają się do siebie i powstaje jądro zygotyczne. [...] Na skutek zapłodnienia dochodzi do: 1) odtworzenia diploidalnej liczby chromosomów, 2) określenia płci przez chromosom X lub Y gamety męskiej, 3) zapoczątkowanie serii podziałów komórkowych [...]"13. Innymi słowy, zaczyna się nieprzerwany, autonomicznie sterowany proces rozwoju zarodkowego, którego efektem będzie dorosły człowiek. Stąd też Kościół może stwierdzić, że „od chwili zapłodnienia komórki jajowej rozpoczyna się życie, które nie jest życiem ojca ani matki, ale nowej ludzkiej istoty, która rozwija się samoistnie. Nie stanie się nigdy człowiekiem, jeżeli nie jest nim od tego momentu. Tę oczywistą prawdę, zawsze uznawaną, [...] nowoczesna genetyka

B. Mariae Virginis”, Rzym 1661, w: Enchiridion symbolorum, nr 2015, 2017; PIUS XII, Encyklika „Humani generis”, Rzym 1950: ,[...] animas enim a Deo immediate creari catholica fides nos retinere iubet [...]” (,wiara katolicka zobowiązuje nas do wierzenia, że dusze zostają bezpośrednio stworzone przez Boga") (AAS 42(1950), 17, 575.

${ }^{12}$ Por. PAPIESKa RADA DS. DusZPasterstwa SŁuŻY ZdROwia, Nowa karta pracowników stużby zdrowia, nr 11-12.

${ }^{13}$ H. BARTEL, Embriologia, wyd. 4, Warszawa 2007, s. 84-85; por. także L. PAWELCZYK, M. SERDYŃSKA, Zapłodnienie, w: Połoznictwo i ginekologia, t. 1, red. G.H. Bręborowicz, Warszawa 2008, s. 5-6; J. WróBEL, Poczęcie człowieka i status jednokomórkowej ludzkiej zygoty z perspektywy bioetyki katolickiej, ,Roczniki Teologiczne” 64(2017), z. 3, s. 79-92; Ontogeneza, w: Wielka encyklopedia medyczna, t. 14, red. E. Cravetto, Warszawa 2011, s. 248. 
potwierdza cennymi dowodami. Ukazała ona, że od pierwszej chwili istnieje dokładny program tego, kim będzie ta żywa istota: człowiekiem, tym konkretnym człowiekiem, którego cechy szczególne są w pełni określone"14.

Powyższe uwagi nie tylko wskazują na nierozdzielną więź każdego człowieka ze swoim Stwórcą i z rodzicami, ale także na jego niezbywalną godność osobową. Taka specyfika natury każdego człowieka czyni go równoprawnym członkiem rodzaju ludzkiego i domaga się uznania jego ontologicznej równości pośród wszystkich innych osób. Jednocześnie chroni go ona przed jakimkolwiek zawłaszczeniem, uprzedmiotowieniem, manipulowaniem i niszczeniem. Odnosi się ona w jednakowym stopniu do dorosłego człowieka, jak i do ludzkiego embrionu od chwili jego poczęcia.

\section{ZAMRAŻANIE LUDZKICH EMBRIONÓW JAKO ELEMENT SKŁADOWY SZTUCZNEJ PROKREACJI}

Zamrażanie ludzkich embrionów jest dziś powszechnie związane z technologią wspomaganego rozrodu (ART - Assisted Reproductive Technology). $\mathrm{W}$ okresie początkowym stosowano uproszczoną procedurę zwaną simple case: starano się zapłodnić jedną komórkę jajową. Metoda ta pozwalała uniknąć produkcji i niszczenia zbędnych (nadliczbowych) embrionów. W takim postępowaniu dostrzegano bowiem zasadnicze zło moralne metod sztucznej prokreacji. Skuteczność takiej procedury okazała się jednak znikoma. Lepszych wyników nie można też było osiągnąć przez zwiększenie częstotliwości zapłodnień, gdyż w jednym cyklu miesięcznym normalnie dojrzewa tylko jeden oocyt. Celem zwiększenia skuteczności prokreacji technicyzowanej nie tylko starano się ulepszyć samą biotechnologię, ale także zwiększyć ilość jednocześnie zapładnianych oocytów. Efekt ten osiąga się przez doprowadzenie do jednoczesnego dojrzewania wielu komórek jajowych. W tym celu wymusza się hiperowulację (indukcję jajeczkowania), stosując hormonalną hiperstymulację kobiety za pomocą leków z gonadotropinami przysadkowymi.

Uzyskane $\mathrm{w}$ ten sposób komórki żeńskie można by zamrozić (co jest możliwe i praktykowane w określonych przypadkach - o czym wspomniano we wstępie) i tylko jedną z nich wykorzystać w procesie sztucznego zapłodnienia. Pozostałe byłyby do dyspozycji w następnych procedurach. Takie postępowanie pozwalałoby uniknąć kolejnej stymulacji hormonalnej kobiety, gdyż zabiegi te nie są obojętne dla jej zdrowia. Jest z nimi związane ryzyko potencjalnie groźnego powikłania zwanego zespołem hiperstymulacji (OHSS

14 JAN PAWE€ II, Encyklika „Evangelium vitae”, Rzym 1995, nr 60. 
- Ovarian Hyperstimulation Syndrome $)^{15}$. Odnotowano przypadki, kiedy stymulacja ta stała się przyczyną śmierci kobiety. Jednakże również ta metoda (zapładniania jednej komórki żeńskiej) nie jest stosowana z powodu praktycznie zerowej skuteczności, a także ograniczeń prawnych zamrażania oocytów.

Nie do pominięcia jest też fakt, że proces zapłodnienia w sztucznych warunkach zwiększa ryzyko komplikacji perinatalnych, ciąży mnogich, powstania wad wrodzonych w embrionie (nawet o 30-40\%), zaburzeń rozwojowych dziecka, zaburzeń metabolicznych, czynnościowych układu sercowo-naczyniowego, ruchowo-kostnych czy też rozwoju chorób nowotworowych ${ }^{16}$. Embriony, rozwijające się wadliwie, przeznacza się do eksperymentów medycznych lub się je porzuca.

$\mathrm{Z}$ punktu widzenia etycznego niszczenie ludzkich embrionów, otrzymanych in vitro lub usuwanych na dalszych etapach rozwoju $\mathrm{z}$ macicy, jest tożsame $\mathrm{z}$ aborcją ${ }^{17}$. Zgodnie z interpretacją kanonu 1398 KPK, przedstawioną przez Papieską Radę ds. Tekstów Prawnych i zatwierdzoną przez pap. Jana Pawła II 23 maja 1988 roku, czyn taki powoduje zaciągnięcie kary ekskomuniki latae sententiae $^{18}$, od której może uwolnić, na podstawie ogólnego upoważnienia

${ }^{15}$ W praktyce klinicznej rozróżnia się postać łagodną OHSS, postać umiarkowaną, postać ciężką i postać krytyczną. Z dwoma ostatnimi postaciami syndromu są związane poważne komplikacje zdrowotne. Z ostatnią postacią wiąże się ryzyko śmierci (por. Zespót Hiperstymulacji, Klinika Leczenia Niepłodności Gameta, https://gameta.pl/blog/zespol-hiperstymulacji/ (dostęp: 17.04.2020).

${ }^{16}$ Por. J. WRÓBEL, Prokreacja technicyzowana - wyzwania etyczne, „Roczniki Teologii Moralnej" 56(2009)3, s. 191-198; T. WASILEWSKI, Procedura in vitro - technika i konsekwencje, w: Wobec in vitro. Genetyczne, moralne, filozoficzne, teologiczne i prawne aspekty zaptodnienia pozaustrojowego, red. J. Grzybowski, F. Longchamps de Bérier, Kielce 2017, s. 38-43; A. MIDRO, Zagrożenia genetycznego dziedzictwa u dzieci poczetych in vitro, w: Wobec in vitro, s. 157-169. Także obfita bibliografia podana przez cytowanych autorów.

${ }^{17}$ Por. PAPIESKA RADA DS. DusZPASTERSTwA SŁUŻBy ZdROwIA, Nowa karta pracowników stużby zdrowia, Rzym 2016, nr 28: „Każde bezpośrednie unicestwienie istoty ludzkiej w okresie pomiędzy poczęciem a narodzinami ma charakter aborcji w pełnym tego słowa znaczeniu".

${ }^{18}$ PONTIFICIA COMmissio CODICI LURIS CANONICI AUTHENTICE INTERPRETANDO, Interpretatio authentica Can. 1398, Patres Pontificiae Commissionis Codici Iuris Canonici Authentice Interpretando propositis in plenario coetu diei 19 ianuarii 1988 dubiis, quae sequuntur, respondendum esse censuerunt ut infra: D. Utrum abortus, de quo in can. 1398, intelligatur tantum de eiectione fetus immaturi, an etiam de eiusdem fetus occisione quocumque modo et quocumque tempore a momento conceptionis procuretur. $R$. Negative ad primam partem; affirmative ad secundam. Summus Pontifex Ioannes Paulus II in Audientia die 23 Maii 1988 infrascripto impertita, de supradictis decisionibus certior factus, eas publicari iussit (AAS 80 (1988), 1818-1819; także http://www.delegumtextibus.va/content/testilegislativi/it/attivita/inter pretazioni/can1398.html (dostęp: 27.10.2018). 
udzielonego przez pap. Franciszka każdy prezbiter w akcie sakramentalnej spowiedzi ${ }^{19}$.

Jeden z istotnych elementów omawianej prokreacji wspomaganej, to wyżej wspomniany transfer embrionów stworzonych w warunkach sztucznych (w przypadku procedury AneVivo w warunkach częściowo naturalnych i częściowo sztucznych) do organizmu matki. Przeniesienia dokonuje się w odpowiednim dniu po owulacji lub po uprzednim hormonalnym przygotowaniu endometrium na ich przyjęcie. Wykształcenie się dojrzałej śluzówki macicy stanowi istotny warunek zagnieżdżenia się w niej embrionów. Z punktu widzenia medycznego $z$ reguły nie jest to zbyt trudny zabieg. Trudności pojawiają się jednak z zagnieżdżeniem wprowadzonych do macicy embrionów. Wystarczy zauważyć, że w naturalnej prokreacji nie wszystkie embriony nawiązują życiodajną łączność $\mathrm{z}$ organizmem matki ${ }^{20}$. W przypadku zabiegów sztucznych także podaje się różne dane na temat skuteczności metod sztucznego zapłodnienia. Warto jednak odnotować, że dane te praktycznie nie zmieniają się od dłuższego czasu. Według badań opublikowanych przez prestiżowy periodyk Europejskiego Towarzystwa Rozrodu Człowieka i Embriologii wydawany przez Oxford University Press, Human Reproduction, przeciętna skuteczność prokreacji wspomaganej w 2004 r. wynosiła 15-18\%, a w 2019 r. $15-19 \%$ (i to po wielu próbach) ${ }^{21}$. Dane te uzupełniają badania ukazujące

${ }^{19}$ Por. FranciszeK, Lettera al Mons. Rino Fisichella Presidente del Pontificio Consiglio per la Promozione della Nuova Evangelizzazione con la quale si concede l'indulgenza in occasione del giubileo straordinario della misericordia, Rzym 2015, http://w2.vatican.va/co ntent /francesco/pl/letters/2015/documents/papa-francesco_20150901_lettera-indulgenza-giubileo-mi sericordia.html (dostęp: 24.04.2020); także wyjaśnienie Papieskiej Rady ds. Tekstów Prawnych, iż w powyższym Liście pap. Franciszka rozgrzeszenie z grzechu aborcji dotyczy również uwolnienia z kary ekskomuniki latae sententiae zaciągniętej przez osoby ponoszące odpowiedzialność za dokonanie aborcji, o czym KPK kan. 1398 i kan. 1355 '2 (por. PonTIFICIUM ConsILIUM DE Legum TeXTiBuS, Resp. Prot. N. 15208/2015, 24 listopada 2015, http://www.delegum textibus.va/content/dam/testilegislativi/risposte-particolari/cic/Circa\%201a\%20facolt\% C3\% A$0 \% 20 \mathrm{di} \% 20$ assolvere $\% 20 \mathrm{dal} \% 2020$ aborto $\% 20$ concessa $\% 20 \mathrm{a} \% 20$ tutti $\% 20$ sacerdoti $\% 20$ per $\% 20$ 1\%27Anno\%20Giubilare.pdf (dostęp: 28.04.2020)). Por. także FrANCISZEK, List apostolski „Misericordia et misera”, Rzym 2016, nr 12.

${ }^{20}$ Różne publikacje podają tutaj rozbieżne dane, ale nie zamieszczają wiarygodnych źródeł tej informacji.

${ }^{21}$ A. Nyboe Andersen, V. Goossens, A.P. Ferraretti, S. Bhattacharya, R. FelberBAUM, J. De Mouzon, K.G. NYGREN, Assisted reproductive technology in Europe, 2004: results generated from European registers by ESHRE [European Society of Human Reproduction and Embryology], „Human Reproduction” 23(2008), nr 4, s. 761; Y. ELMOKHALLALati, R. VAn EeKelen, S. Bhattacharya, D.J. McLernon, Treatment-independent live birth after in-vitro fertilisation: a retrospective cohort study of 2,133 women, „Human Reproduction” 34(2019), nr 8, s. 1470, 1473. Por. także dane przytoczone w następnym przypisie. Ze swej strony Kongregacja Nauki Wiary, opierająca się na miarodajnych źródłach, podaje: „Prawdą 
skuteczność transferu uzyskanych embrionów: rodzi się tylko 19-30\% embrionów przeniesionych do łona matki. Oznacza to, że aż 70-81\% z nich obumiera lub zostaje poronionych ${ }^{22}$. Niską efektywność pozaustrojowego zapłodnienia komórek jajowych i transferu embrionów do łona matki próbuje się przezwyciężyć w sposób sztuczny. Stosując wspomnianą hiperowulację, uzyskuje się większą ilość komórek jajowych - przeważnie od 6 do 8, ale niekiedy nawet do $20^{23}$. Zapładnia się je poza organizmem matki i następnie stosując diagnozę preimplantacyjną (opóżniając w tym celu transfer do macicy do pięciu dni, a w przypadku wątpliwości nawet do siedmiu dni ${ }^{24}$, wybiera się dobrze zapowiadające się embriony. Podstawą tej oceny jest między innymi prawidłowo dokonujący się podział komórkowy embrionu ${ }^{25}$. Dokładniejsza

jest, że blisko jedna trzecia kobiet, które uciekają się do metod sztucznego przekazywania życia, rodzi dziecko. Trzeba jednak zaznaczyć, że biorąc pod uwagę stosunek wszystkich wyprodukowanych embrionów do embrionów rzeczywiście narodzonych, liczba embrionów zniszczonych jest bardzo wysoka”. W przypisie nr 27 Kongregacja dodaje: „Obecnie nawet w największych ośrodkach wykonujących zabiegi sztucznego zapłodnienia liczba zniszczonych embrionów przekracza 80\%” (Instrukcja „Dignitas personae” dotyczqca niektórych problemów bioetycznych, Rzym 2008, nr 14).

${ }^{22}$ Według badań European Society of Human Reproduction and Embryology (ESHRE) przeprowadzonych w 2006 roku dane te przedstawiają się w poszczególnych europejskich krajach: Polska 31,4\% (na 3684 transferowanych - 1159 urodzonych), Belgia 19\% (2876 transf. - 565 urodz.), Bułgaria 25\% (1089 transf. - 280 urodz.), Dania 24\% (8253 transf. - 1993 urodz.), Francja 24\% (41395 transf. - 9982 urodz.), Niemcy 19\% (36875 tranf. - 7040 urodz.), Włochy 14,5\% (28315 transf. - 4129 urodz.) (J. De Mouzon, V. Goossens, S. Bhattacharya, J.A. Castilla, A.P. Ferraretti, V. Korsak, M. Kupka, K.G. Nygren, A. Nyboe Andersen, Assisted reproductive technology in Europe, 2006: results generated from European registers by ESHRE [European Society of Human Reproduction and Embryology], „Human Reproduction” 25(2010), nr 8, s. 1855-1856. Analogiczne dane podaje Papieska Rada ds. Duszpasterstwa Służby Zdrowia: ,[...] dla urodzenia jednego dziecka akceptuje się utratę około 80\% skutecznie przeniesionych embrionów" (Nowa Karta Pracowników Stużby Zdrowia, nr 28).

${ }^{23}$ Por. T. WASILEWSKI, Procedura in vitro, 38; In vitro - IVF - Zapłodnienie pozaustrojowe, INVICTA. Klinika Leczenia Niepłodności, https://www.klinikainvicta.pl/leczenie-nieplod nosci/metody-leczenia/zaplodnienie-in-vitro/ (dostęp: 09.05.2020).

${ }^{24}$ Por. Forum embriologiczne: Od czego zależy, na jakim etapie zarodek zostaje zamrożo$n y$, Portal Przychodni Leczenia Niepłodności ,nOvum”,https://www.novum.com.pl/pl/leczenieni eplodnosci/forum-embriologiczne/strona/1/\#accordion-faq-111-7253 (dostęp: 24.04.2020).

25 Warto zauważyć, że taka diagnoza nie zawsze daje pewny wynik, gdyż brak symetrii w podziale embrionu niekoniecznie zapowiada dalszy jego nieprawidłowy rozwój (por. Forum embriologiczne: Co oznacza opis zarodka cl5.3 zamrożonego w 2 dniu, jaka jest jego jakość?, Portal Przychodni Leczenia Niepłodności „nOvum”, https://www.novum.com.pl/pl/leczenie-nieplodnosci/fo rum-embriologiczne/strona/0/\#accordion-faq-111-7554 (dostęp: 24.04.2020); także Forum embriologiczne: Czy mam szansę na pozytywny crio transfer z zamrożonych 3-dniowych zarodków: $\mathrm{cl} 9.3$ i cl 10.3?, Portal Przychodni Leczenia Niepłodności „,nOvum”, https://www. novum.com.pl/pl/leczenie-nieplod nosci/forum-embriologiczne/strona/0/\#accordion-faq-111-7526 (dostęp: 24.04.2020)). 
metoda polega na pobraniu z embrionu jednej lub kilku komórek i na poddaniu ich kariotypu specjalistycznej analizie ${ }^{26}$. Spośród zapłodnionych embrionów i zdrowo się rozwijających do macicy matki transferuje się przeważnie od jednego do trzech (w USA nawet więcej niż pięć) ${ }^{27}$. Po kilku dniach od transferu kontroluje się przebieg ich implantacji i spośród tych, które zagnieździły się pomyślnie, jednemu, a wyjątkowo za zgodą rodziców dwom, pozwala się na dalszy rozwój. Jeżeli rodzice wyrażają zgodę tylko na jeden-dwa embriony, pozostały(e) zostaje(ą) abortowany(e), gdyż ciąża mnoga nie jest korzystna ani dla matki, ani dla rozwoju ludzkich płodów. Najczęstsze konsekwencje ciąży mnogich to między innymi: ,poronienia, przedwczesny poród, [...] niska masa urodzenia dziecka, [...] większe ryzyko pojawienia się wad rozwojowych, podwyższone ryzyko wystąpienia u matki cukrzycy, nadciśnienia, niewydolności krążenia [...]"28. Nadliczbowe embriony uzyskane in vitro wolne od wad poddaje się procesowi zamrażania na etapie rozwoju od stadium przedjądrzy do blastocysty.

Stworzony metodą zamrażania zapas embrionów pozwala uniknąć ponawiania całej procedury (przede wszystkim stymulacji hormonalnej kobiety, perforacji powłoki brzusznej i punkcji jajników), jeżeli zapłodnienie lub transfer się nie powiedzie. Procedura zamrażania embrionów jest między innymi stosowana:

- kiedy kobieta musi poddać się leczeniu onkologicznemu mogącemu zniszczyć jajniki i spowodować niepłodność (chemioterapia, radiologiczne naświetlania);

${ }^{26}$ Por. T. WASILEWSKI, Procedura in vitro, 38-39. Kliniki praktykujące prokreację technicyzowaną informują zainteresowane osoby, że w czasie procedury prowadzą „,badania preimplantacyjne PGS oraz PGD, których głównym zadaniem jest określenie, czy u potomstwa występuje ryzyko wystąpienia chorób genetycznych. [...] Screeing przedimplantacyjny PGS to genetyczne badanie przesiewowe, polegające na ocenie liczby wszystkich par chromosomów w jednej lub kilku komórkach zarodka. Zarodki z nieprawidłową liczbą chromosomów [...] [posiadaja] zbyt niski potencjał rozwoju, co może powodować poronienie lub poród chorego dziecka. [...] PGD jest badaniem kierunkowym, w którym poszukiwana jest konkretna nieprawidłowość genetyczna" (Wykrycie wad genetycznych podczas in vitro. Gyncentrum. Klinika leczenia niepłodności i diagnostyki prenatalnej, https://www.gyncentrum. pl/blog/pl/wykryciewad-genetycznych-podczas-in-vitro, (dostęp: 17.04.2020).

Należy dodatkowo podkreślić, że taka diagnoza posiada własną ciężką niemoralność, gdyż prawie każdy blastomer oderwany od zarodka zachowuje zdolność totipotencjalną (wszechpotencjalną), czyli ma zdolność dalszego samodzielnego rozwoju, stanowiąc zaczątek nowego człowieka - bliźniaka monozygotycznego.

${ }^{27}$ Por. Transfer zarodków, PARENS. Centrum Leczenia Niepłodności, http://parens.pl/je stem-w-trakcie-leczenia/transfer-zarodkow/ (dostęp: 19.04.2020).

${ }^{28}$ Transfer zarodków, PARENS. Centrum Leczenia Niepłodności, http://parens.pl/jestem-wtrakcie-leczenia/transfer-zarodkow/ (dostęp: 19.04.2020). 
- w przypadku kobiet, dla których stymulacja hormonalna jest źródłem niekorzystnych efektów ubocznych, na przykład, jeżeli jest źródłem złego samopoczucia lub wywołuje OHSS;

- kiedy kobiety nie mogą lub nie chcą w tym momencie zdecydować się na kolejne dziecko i decyzję tę odkładają na późniejszy czas.

Normalnie komórki ssaków mogą żyć w przedziale temperatur od 34 do $42^{\circ} \mathrm{C}$. Dłuższe przechowywanie embrionów w sztucznych warunkach domaga się ich zamrożenia. W ten sposób zostają zatrzymane procesy życiowe, a tym samym zużywanie zapasów energetycznych potrzebnych dla rozwoju do czasu implantacji w śluzówce matki umożliwiającej pobieranie od niej substancji odżywczych i wydalanie szkodliwych substancji będących efektem przemiany materii.

Proces kriokonserwacji embrionów jest skomplikowany i ryzykowny. Jak już podkreślono we wstępie, muszą być one chronione przed tworzeniem się w czasie zamrażania kryształków lodu niszczących ich wewnętrzną strukturę oraz przed zmianami właściwości białkowo-lipidowych błon komórkowych. Cel ten osiąga się na dwa sposoby: stosując metodę "powolnego zamrażania" (slowfreezing) lub ,szybkiego zamrażania” (vitrification). Pierwsza metoda polega na dehydratacji komórek embrionu. W tym celu zmienia się właściwości płynu komórkowego przez podanie wspomnianych we wstępnie krioprotektantów. Należą do nich między innymi polialkohole oraz cukry proste, jak glikol polietylenowy, glicerol, glukoza czy sacharoza. Substancje te „wypychają" wodę z komórek (dehydratacja) i chronią je przed tworzeniem się wspomnianych kryształków lodu ${ }^{29}$.

Druga metoda, uważana (niesłusznie) za bardziej bezpieczną, polega na odpowiednim sterowaniu procesem zamrażania. Jej istotę stanowi podanie wysokiego stężenia krioprotektantów i wymuszenie błyskawicznego przejścia płynu komórkowego ze stanu wodnistego do stałego - zeszklenia. W praktyce metoda ta polega na nagłym wprowadzeniu przygotowanych embrionów do ciekłego azotu $\left(-196^{0} \mathrm{C}\right)^{30}$. Proces rozmrażania embrionu i (re)hydratacji jest

${ }^{29}$ Por. Mrożenie zarodków - kriokonserwacja, INVICTA. Klinika Leczenia Niepłodności, https://www.klinikainvicta.pl/nieplodnosc-faq/mrozenie-zarodkow-kriokonserwacja/ (dostęp: 19.04.2020).

${ }^{30}$ Por. A. NiWIŃsKA, Przeglad metod kriokonserwacji, s. 506-508; B. WoJTASIK, Witryfikacja, czyli szybkie mrożenie zarodków i gamet, InviMed. Kliniki leczenia niepłodności, https://www.invimed.pl/ witryfikacja-czyli-mrozenie-zarodkow-i-gamet (dostęp: 19.04.2020); Mrożenie zarodków - kriokonserwacja, INVICTA. Klinika Leczenia Niepłodności, https://w ww.klinikainvicta.pl/nieplodnosc-faq/mrozenie-zarodkow-kriokonserwacja/(dostęp:19.04.2020). Chociaż powszechnie uważa się tę metodę za bezpieczniejszą, to jednak również z nią jest związane duże ryzyko, którego źródłem jest „niezbędne wysokie stężenie toksycznych krioprotektantów”. „Badania z lat 90. wykazały także niejasną zależność między narażeniem wysokimi 
jeszcze bardziej ryzykowny niż dehydratacja lub witryfikacja. Z jednej strony procedura ta musi się dokonywać stosunkowo powoli, aby mogło nastąić wydalenie krioprotektantów i przywrócenie naturalnych właściwości płynowi komórkowemu, a z drugiej strony musi się ona dokonać dostatecznie szybko, aby komórki w czasie rehydratacji nie zostały uszkodzone lub zniszczone powstającymi kryształkami lodu. Ten sam embrion raz zamrożony i rozmrożony, jeżeli posiada odpowiedni potencjał życiowy, może być ponownie poddany tej procedurze ${ }^{31}$.

Kliniki zajmujące się prokreacją wspomaganą i świadczące usługi w zakresie przechowywania ludzkich gamet i embrionów podają, że w $90 \%$ (inne aż w 99\%) zabiegi te daja pozytywny wynik. Warto jednak odnotować, że według badań przeprowadzonych w Europie w 2005 roku średnio aż 85-90\% zamrożonych embrionów obumierało ${ }^{32}$. Według badań opublikowanych w 2014 roku proces zamrażania i rozmnażania przeżywa 65-70\% zarodków, ale tylko $10-15 \%$ z nich zostaje donoszonych i urodzonych przez matki ${ }^{33}$. Z kolei według danych - podanych w 2016 r. przez amerykańską Society for Assisted Reproductive Technology - tylko 32,4\% rozmrożonych embrionów się urodzi ${ }^{34}$. Dane te w pełni pokrywają się ze stwierdzeniem Kongregacji Nauki Wiary, która korzystając z własnych źródeł informacji stwierdza

stężeniami DMSO w medium witryfikacyjnym a wysokimi stratami prawidłowo rozwijających się zarodków w fazie poimplantacyjnej. W innych badaniach z narażeniem na krioprotektanty wiązano także rozpad chromosomów, zwiększone występowanie aneuploidii i inne chromosomalne nieprawidłowości, a także rozwój zniekształconych płodów z komórki wcześniej uznanej za rozwijającą się prawidłowo" (A. NiwiŃSKA, Przeglad metod kriokonserwacji, s. 507).

${ }^{31}$ Por. Forum embriologiczne. Ile i które zarodki wybrać do kriotransferu?, Portal Przychodni Leczenia Niepłodności ,nOvum”, https://www.novum.com.pl/pl/leczenie-nieplodnosci/fo rum-embriologiczne/pytanie/512/ (dostęp: 19.04.2020).

32 Por. A. Nyboe Andersen, V. Goossens, S. Bhattacharya, A.P. Ferraretti, M.S. KupKA, J. DE Mouzon, K.G. NYGREn, Assisted reproductive technology and intrauterine inseminations in Europe, 2005: results generated from European registers by ESHRE, Human Reproduction 24(2009), nr 1, s. 10 (tabela nr VIII).

33 A. NIWIŃSKA. Przeglad metod kriokonserwacji, s. 505-507; Witryfikacja zarodków i oocytów, Gyncentrum. Klinika Leczenia Niepłodności i Diagnostyki Prenatalnej, https://www. gyncentrum.pl/witryfikacja-zarodkow-i-oocytow (dostęp: 27.10.2018); Kriokonserwacja komórek jajowych i zarodków, „GMW - Embrio”, http://invitro gmw.pl/nieplodnosc-2/pracownia-em briologiczna/kriokonserwacja-zarodkow/ (dostęp: 27.10.2018); J. BISZEWSKA-MIĘTKA, Mrożenie zarodków - sposób na odłożenie macierzyństwa w czasie?, http://www.edziecko.pl/przed_ciaza/1,87842,153 55849,Mrozenie_zarodkow_sposobnaodlozenie_macierzynstwa.html (dostęp: 27.10.2018).

34 Society for Assisted Reproductive Technology, IVF Success. 2016 Preliminary National Data, https://www.sartcorsonline.com/rptCSR_PublicMultYear.aspx?reporting Year= 2016\#help (dostęp: 27.10.2018). 
w 2008 r., że ,znaczący procent [embrionów] nie przeżywa procesu zamrożenia i rozmrożenia" 35 .

Aktualnie nie jest możliwe dokładne określenie ilości zamrożonych embrionów. Według obliczeń z 2013 r. na świecie około miliona dzieci doświadczyło zamrożenia. Przypuszcza się, że aktualnie w Polsce może ich być kilkadziesiąt tysięcy.

Pozostaje jeszcze pytanie, jak długo embriony moga pozostać w stanie zamrożenia? Przedstawiciele ośrodków światowych, które przeprowadziły badania nad kriokonserwacją embrionów, mówią o pozytywnych wynikach nawet długotrwałego ich przechowywania w tym stanie ${ }^{36}$. Przeprowadzone badania sugerują też, że długość ich przechowywania w zamrożeniu nie ma wpływu na skuteczność dalszej procedury ${ }^{37}$. W Chinach przyszło na świat dziecko, które jako embrion było zamrożone przez 16 lat $^{38}$. Najdłuższy stwierdzony dotychczas czas przechowywania embrionu w zamrożeniu wyniósł 19 lat i 7 miesięcy ${ }^{39}$. W polskiej Przychodni Leczenia Niepłodności „nOvum” okres ten wyniósł do 11 lat ${ }^{40}$. Od jakiegoś czasu dominuje też opinia, że ludzkie zarodki mogą pozostać w zamrożeniu bardzo długo. Polska klinika „Gyncentrum” informuje, że jest gotowa przechowywać zarodki dowolnie długo ${ }^{41}$.

35 Instrukcja dotycząca niektórych problemów bioetycznych Dignitas personae, nr 18.

${ }^{36}$ Por. J.H. Check, D. Summers-Chase, W. Yuan, K. Swenson, D. Horwath B CAMDEN, Length of time of embryo storage does not negatively influence pregnancy rates after thawing and transfer, „Clinical and Experimental Obstetrics and Gynecology” 37(2010), nr 3, s. 185-186; R. Riggs, J. MaYer, D. Dowling-Lacey, T.-F. Chi, E. Jones, S. Oehninger, Does storage time influence post thaw survival and pregnancy outcome? An analysis of 11,768 cryopreserved human embryos, „Fertility and Sterility” 93(2010), nr 1, s. 109-115.

${ }^{37}$ Por. R. Riggs, J. Mayer, D. Dowling-Lacey, T.-F. Chi, E. Jones, S. Oehninger, Does storage time in uence postthaw survival and pregnancy outcome?, 109.

${ }^{38}$ M. PStRĄG, Z zarodka zamrożonego przez 16 lat urodzito się zdrowe dziecko! https:// mamotoja.pl/mrozenie-zarodkow-do-in-vitro-to-bezpieczne-przez-dlugie-lata,in-vitro-artykul,22 282,r1p1. html (dostęp: 27.04.2020).

39 D. Dowling-Lacey, J.F. Mayer, E. Jones, S. Bocca, L. Stadtmauer, S. OehninGER, Live birth from a frozenBthawed pronuclear stage embryo almost 20 years after its cryopreservation, 1120.e1.

${ }^{40}$ Por. K. PAPIS, P. LeWANdowsKI, J.K. WOLSKI, K. KoZIOE, Dzieci urodzone z zarodków przechowywanych $w$ stanie zamrozenia, s. 971.

${ }^{41}$ Witryfikacja zarodków i oocytów, Gyncentrum. Klinika leczenia niepłodności i diagnostyki prenatalnej, https://www.gyncentrum.pl/witryfikacja-zarodkow-i-oocytow (dostęp: 27.10.2018). 


\section{ZAMRAŻANIE LUDZKICH EMBRIONÓW W ŚWIETLE NAUCZANIA KOŚCIOłA KATOLICKIEGO}

Po raz pierwszy Kościół katolicki wypowiedział się w kwestii prokreacji wspomaganej już pod koniec XIX wieku. Na pytanie ,An adhiberi possit artificialis mulieris foecundatio?” („Czy można stosować sztuczne zapłodnienie kobiety?"), ówczesne Święte Oficjum odpowiedziało (za zgodą Ojca Świętego, Leona XIII, z 26.03.1897): „Non licere” („Nie można”) ${ }^{42}$. Następnie czterokrotnie wypowiedział się $\mathrm{w}$ tej sprawie pap. Pius $\mathrm{XII}^{43}$. W dalszej kolejności pap. Jan XXIII w encyklice Mater et Magistra ${ }^{44}$, pap. Jan Paweł II w encyklice Evangelium vitae w części poświęconej aktualnym zagrożeniom życia ludzkie$\mathrm{go}^{45}$ oraz pap. Benedykt XVI w encyklice Caritas in veritate w ramach analiz związanych z kulturą techniczną i z biotechnologiami ${ }^{46}$.

W najmłodszych z tych dokumentów obok tematyki prokreacji technicyzowanej jest też omawiane wytwarzanie nadliczbowych embrionów oraz ich kriokonserwacja. Dotyczy to dwóch przemówień pap. Jana Pawła $\mathrm{II}^{47}$, dwóch dokumentów Kongregacji Nauki Wiary ${ }^{48}$ oraz dwóch dokumentów Papieskiej Rady ds. Duszpasterstwa Służby Zdrowia ${ }^{49}$.

Wszystkie przedstawione dokumenty i wypowiedzi Stolicy Apostolskiej jednoznacznie oceniają jako głęboko niemoralną prokreację wspomaganą, tak

${ }^{42}$ Por. SACRUM OFFICIUM, Fecondazione artificiale, Roma 1897, ASS 29(1896-1897), 704; Denz 3323; por. także J. WRóBEL, Prokreacja technicyzowana, s. 184.

${ }^{43}$ Por. Do Uczestników IV Międzynarodowego Kongresu Lekarzy Katolickich (29.09.1949), AAS 41(1949), 557-561; Do Uczestników Kongresu Katolickiej Unii Położnych Wtoskich (29.10.1951), AAS 43(1951), 838-844; Do Uczestników II Światowego Kongresu na temat płodności i bezptodności (19.05.1956), AAS 48(1956), 467-474; Do Uczestników VII Międzynarodowego Kongresu Światowej Organizacji Hematologii (12.09.1958), AAS 50(1958), 732740; por. J. WróBel, Prokreacja technicyzowana, s. 184.

${ }^{44}$ Por. Rzym 1961, nr 193.

45 Por. Rzym 1995, nr 14.

46 Por. Rzym 2009, nr 75.

${ }^{47}$ Przemówienie do uczestników sympozjum na temat „Evangelium vitae” a prawo i na XI Międzynarodowym Kolokwium Prawa Kanonicznego, „L'Osservatore Romano” (PL) 1996, nr 9, s. 44; AAS 88(1996), 943-944.

${ }^{48}$ Instrukcja o szacunku dla rodzacego się życia ludzkiego; Instrukcja dotyczaca niektórych problemów bioetycznych „Dignitas personae”.

${ }^{49}$ Karta pracowników stużby zdrowia, nr 21-34; Nowa karta pracowników stużby zdrowia. Inne dokumenty, w których jest omawiana problematyka sztucznej prokreacji, to: PAPIESKA AKADEMIA „PRO VITA”, Refleksje na temat klonowania (Rzym 1997), PAPIESKA RADA DS. RodzINY, Rodzina i prokreacja ludzka (Rzym 2006) oraz PAPIESKA AKADEMIA „PRO VitA”, Ludzki embrion $w$ fazie preimplantacyjnej. Aspekty naukowe i refleksje bioetyczne (Rzym 2006). 
w formie sztucznej inseminacji (in vivo), sztucznego zapłodnienia (in vitro), jak i zamrażania ludzkich embrionów. Moralne zło tych biotechnologii tkwi w ewidentnym deptaniu godności osobowej embrionów, w ich uprzedmiotawianiu, niszczeniu i w wystawianiu na ryzyko chorób wrodzonych. Specjalista, przeprowadzający zabieg, stawia siebie w pozycji dominującej nad embrionami, uzurpuje sobie prawo do decydowania o ich życiu i o ich losie, wystawia je na ryzyko zniszczenia lub naruszenia ich delikatnej struktury warunkującej ich zdrowy rozwój. Z kolei niespełniające oczekiwań zdrowotnych lub nieposiadające pożądanej płci, zostają odrzucone. Arbitralnie decyduje on też, które embriony będą przeniesione do łona matki, a które zamrożone. Najczęściej w chwili zamrożenia nie jest też wiadome, jak długo pozostaną one w tym stanie, czy będą rozmrożone, czy przeżyją ten proces, czy podejmą na nowo procesy życiowe, czy stan ich zdrowia pozwoli na ich transfer do łona matki. W kręgu powyższych zastrzeżeń pojawia się też niekiedy problem skazania zamrożonych embrionów na pozostanie sierotami. Zdarza się bowiem, że rodzice nie chcą ich więcej lub ze względów zdrowotnych, ewentualnie losowych, nie mogą ich już przyjąc ${ }^{50}$.

\section{ZAMRAŻANIE EMBRIONÓW JAKO WYZWANIE MORALNE}

Zamrażanie ludzkich embrionów niesie ze sobą trudne kwestie moralne. Dotyczą one zwłaszcza społecznych odniesień do takich praktyk oraz rozwiązania problemu zamrożonych embrionów.

\section{Społeczne odniesienia do prokreacji wspomaganej i zamrażania embrionów}

Zgodnie z wcześniejszymi uwagami procedura prokreacji wspomaganej, jak i manipulacje czynione na ludzkich embrionach, w tym ich zamrażanie, są aktami wielce niemoralnymi i nic nie może ich usprawiedliwić. Taka ich ocena nie może być jednak przenoszona na dzieci zrodzone w powyższy sposób. Również one są obdarowane niezbywalną godnością osobową i konsekwentnie mają takie same prawa społeczne i kościelne, jak dzieci zrodzone naturalnie. Mają więc one pełne prawo do chrztu św., do pozostałych sakramentów świętych oraz do pełnoprawnego uczestnictwa w życiu wspólnoty świeckiej i kościelnej. Konsekwentnie nie mogą one być stygmatyzowane,

${ }^{50}$ Por. Kongregacja NAUKI WiARY, Instrukcja „Donum vitae”, nr I, 6; także TENŻE, Instrukcja „Dignitas personae”, nr 18; J. WRÓBEL, Prokreacja technicyzowana, s. 186-198; TENŻE, Antropologiczne implikacje sztucznej prokreacji, ,Roczniki Teologiczne” 62(2015), z. 3, s. 79-97 (cały s. 77-100). 
poniżane i marginalizowane z powodu swojego pochodzenia. Przez wszystkich winny być przyjęte z serdecznością i miłością ${ }^{51}$.

Wielokrotne wypowiedzi Kościoła na temat równego traktowania wszystkich dzieci, bez jakichkolwiek oznak rasizmu, poniżania czy faworyzowania jednych kosztem drugich, stanowią istotne zobowiązanie dla katolików oraz dla każdego człowieka „dobrej woli”. Powinny one sięgać samej głębi jego sumienia. Stąd pełne miłości przyjęcie dzieci poczętych in vitro nie może wymuszać przemilczania prawdy o wartości samej procedury i jej skutków. Społeczne piętnowanie przedstawionego traktowania dzieci nie narusza praw autorów procedury, gdyż - jak podkreśla Jan Paweł II - „,wolność sumienia nie jest nigdy wolnością «od» prawdy, ale zawsze i wyłącznie «w» prawdzie, lecz także dlatego, iż Magisterium nie wprowadza do chrześcijańskiego sumienia prawd mu obcych, a tylko objawia prawdy, które sumienie powinno już znać i rozwijać je"52.

Nauczanie Kościoła na temat sztucznej prokreacji pragnie również uwrażliwić angażujące się w niej osoby na odpowiedzialność za psychiczną traumę stwarzanych w ten sposób dzieci z chwilą, kiedy poznają one swoją genezę oraz los ich uśmierconego rodzeństwa, któremu zawdzięczają swoje życie. Odpowiedzi na stawiane przez nie trudne pytania nie da się uniknąć stwierdzeniem, że wtedy nie miały jeszcze człowieczego statusu, że ich stworzenie było motywowane miłością i pragnieniem ich posiadania. Poznanie przez nie prawdy o ich początkach prowadzi do emocjonalnych zaburzeń i do zerwania więzów rodzinnych.

W powyższym kontekście trzeba odnotować przewrotny zarzut wysuwany pod adresem osób świeckich i duchownych, które publicznie przypominają o niemoralności omawianych metod, o uśmiercaniu w nich dzieci lub o ich zdrowotnych następstwach opisywanych w prestiżowych periodykach naukowych. Osobom tym zarzuca się, że publicznie stygmatyzują dzieci zrodzone z pomocą sztucznych metod i utrudniają rozwijanie przez nie pozytywnych relacji ze swoimi rodzicami. Przewrotność tych oskarżeń wyraża się w tym, że obrońcy godności i praw dzieci nie mają na celu wyjawienia im ich historii, gdyż najczęściej ich nie znają, ale starają się uwrażliwiać społeczeństwo na moralną odpowiedzialność za te praktyki oraz za ich następstwa. Przewrotność tych ataków polega też na tym, że ich autorzy ewidentnie akceptują krzywdę wyrządzaną dzieciom stworzonym

${ }^{51}$ Por. PAPIESKa RADA DS. DUSZPASTERSTwa SŁUŻBy ZdRowia, Nowa karta pracowników stużby zdrowia, nr 32: „Jakkolwiek, nawet nie mogąc zaaprobować trybu, w jakim dokonano zapłodnienie, każde dziecko przychodzące na świat powinno być przyjęte jako żyjący dar Dobroci Bożej i powinno być z miłościa wychowywane”. Por. także KongregaCJA NAUKI WIARY, Instrukcja „Donum vitae”, II, B, 5.

52 Encyklika „Veritatis splendor”, Rzym 1993, nr 64. 
in vitro i chcą wymusić na całym społeczeństwie jej zaakceptowanie oraz przemilczanie wyrządzanych niesprawiedliwości.

\section{Zamrażanie embrionów - „niesprawiedliwość nie do naprawienia”}

Zgodnie z wcześniejszymi uwagami szacunek należny embrionom wyklucza ich kriokonserwację, gdyż oznacza ona ich uprzedmiotowienie, a także wiąże się z nią duże ryzyko ich uśmiercenia, uszkodzenia uniemożliwiającego ich dalszy rozwój lub spowodowanie ich przyszłego kalectwa. Nie dotyczy to tylko nadliczbowych embrionów. Niekiedy zamrożony musi być już pierwszy $\mathrm{z}$ otrzymanych embrionów. Powodem mogą być problemy zdrowotne matki, między innymi komplikacje uniemożliwiające wykształcenie się endometrium warunkującego skuteczne zagnieżdżenie się w nim blastocysty. Zdarzają się też sytuacje, kiedy embrion zostaje sierotą na samym początku jego istnienia, kiedy zostaje on porzucony przez rodziców, albo też jego matka umiera lub ginie $\mathrm{w}$ wypadku ${ }^{53}$.

W wyniku stosowanych procedur lub opisanych zdarzeń w klinikach praktykujących sztuczną prokreację przechowuje się „tysiące” zamrożonych embrionów. Powstaje pytanie, czy można rozwiązać ten problem w sposób moralnie akceptowalny? Dla przedstawionych wcześniej racji niemoralne jest wyrzucanie czy też uśmiercanie tych embrionów ${ }^{54}$. Aktu takiego nie mogą usprawiedliwić normy prawa stanowionego, które w niektórych krajach bądź na to pozwalają, bądź też wprost nakazują to czynić. Ponad prawem stanowionym stoi bowiem prawo naturalne oraz prawa embrionów jako dzieci wynikające z ich godności. Nie jest też dopuszczalne wykorzystanie wyprodukowanych embrionów do celów naukowych czy też terapeutycznych jako, na przykład, dawców komórek macierzystych, czy też jako materiał biologiczny do tworzenia embrionalnych linii komórkowych ${ }^{55}$. Kongregacja Nauki Wiary zaznacza ponadto, że „nie do przyjęcia jest też rozmrażanie embrionów bez ich reaktywacji" celem ich wykorzystania w badaniach, w eksperymentach czy w produkcji szczepionek jako „materiał biologiczny"56.

53 Por. KongregacJa NAUKI WIARY, Instrukcja „Dignitas personae”, nr 18; PAPIESKA RADA DS. DUSZPASTERSTWA SŁUŻBy ZdROwiA, Nowa karta pracowników stużby zdrowia, nr 37.

${ }^{54}$ Akt taki ma znamiona zabójstwa istoty ludzkiej, niezależnie od tego, w jaki sposób i w którym momencie od poczęcia do urodzenia zostaje dokonane (por. JAN PAWEŁ II, Encyklika „Evangelium vitae”, nr 58; por. także KongREGACJA NAUKI WIARY, Deklaracja „De abortu procurato”, Rzym 1974; także Instrukcja „Donum vitae”, nr I, 5.

${ }^{55}$ Por. Kongregacja NAUKI WIARY, Instrukcja „Donum vitae”, nr I, 4.

56 Kongregacja NaUki Wiary, Instrukcja „Dignitas personae”, nr 19, 34-35. 
Wobec powyższych stwierdzeń dobrym rozwiązaniem mogłaby się wydawać adopcja prenatalna, czyli przekazanie nadliczbowych embrionów małżeństwom (nie tylko niepłodnym) lub kobietom, które chciałyby je urodzić. Propozycje te, chociaż wydają się być szlachetne, to jednak posiadają cechy, które je dyskwalifikują z perspektywy etycznej, ,medycznej, psychologicznej i prawnej". Występują tutaj bowiem te same zastrzeżenia, dla których niegodziwe jest zapłodnienie heterologiczne i macierzyństwo zastępcze ${ }^{57}$.

Niemoralność takich rozwiązań wynika z wrodzonych dziecku praw. Kongregacja Nauki Wiary wyjaśnia ze swej strony: „dziecko ma prawo do tego, by zostać poczętym, by być noszonym w łonie, narodzonym i wychowanym

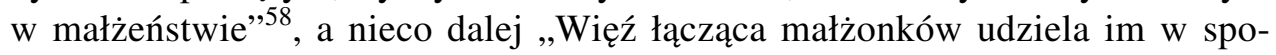
sób obiektywny i niezbywalny wyłącznego prawa do stania się ojcem i matką jedynie dzięki sobie"59. Ich godność jako małżonków zostaje afirmowana wyłącznie przez ich jedność wyrażająca się nie tylko we wspólnocie życia, ale także w akcie przekazania życia i zrodzenia ich własnego potomstwa. Urodzenie nieswojego dziecka wykracza poza ramy tej jedności i nie wchodzi w zakres praw właściwych małżonkom ${ }^{60}$. Z kolei urodzenie go przez nieswoich rodziców redukuje go do poziomu istoty mogącej być do dyspozycji drugiego człowieka i bycia traktowanym jako obiekt wymiany między osobami.

W dalszej perspektywie należy też dostrzec inne jeszcze efekty takiego rozwiązania problemu zamrożonych embrionów. W grę wchodzi zwiększone ryzyko odrzucenia dziecka po urodzeniu jako nieswojego, jeżeli zostanie ono uznane za nieodpowiadające oczekiwaniom osób adoptujących (np. jego płeć czy fenotyp) lub jeżeli urodzi się ono obciążone wrodzonymi wadami (co zgodnie z wcześniejszymi uwagami jest bardziej prawdopodobne w przypadku procedury in vitro oraz zamrażania embrionów, niż w przypadku dziecka poczętego naturalnie). Dla powyższych powodów należy również wyrazić obawę, że w przedstawionych przypadkach zdecydowanie zwiększa się ryzyko aborcji niechcianego lub chorego dziecka.

W odpowiedzi na coraz powszechniejszą praktykę zamrażania embrionów Jan Paweł II podkreśla, że ,tysiące porzuconych embrionów stwarzają sytuację niesprawiedliwości nie do naprawienia [...] zważywszy, że nie ma moralnie godziwego rozwiązania, które zapewniłoby ludzką przyszłość wielu ty-

57 Por. Kongregacja NAUKI WiARY, Instrukcja „Dignitas personae”, nr 19; PAPIESKA RADA DS. DUSZPASTERSTWA SŁUŻBy ZDROWIA, Nowa karta pracowników stużby zdrowia, nr 37.

${ }^{58}$ Kongregacja Nauki Wiary, Instrukcja „Donum vitae”, nr II, A, 1.

59 Tamże, nr II, A, 2.

${ }^{60}$ Por. tamże, nr II, A, 2. 
siącom «zamrożonych» embrionów, choć przecież mają one i zawsze zachowają swoje podstawowe prawa"61.

\section{Możliwe rozwiązania problemu zamrożonych embrionów}

Przytoczone słowa Jana Pawła II, że „,nie ma godziwego rozwiązania problemu zamrożonych embrionów", należy ściśle interpretować. Nie mogą być bowiem one odniesione do wszystkich zarodków przetrzymywanych w ciekłym azocie. Papież ma ewidentnie na myśli embriony porzucone przez rodziców, wyprodukowane w ramach eksperymentów biomedycznych lub te, które dla różnych powodów nie mogą być transferowane do łona matki. Mając na uwadze los tych embrionów, Penitencjaria Apostolska odpowiedziała na postawione jej pytanie: ,nie posiadając faktycznie możliwości moralnie pewnych do rozwiązania problemu, przerwać proces zamrożenia i pozwolić umrzeć w pokoju tym embrionom, jest moralnie dopuszczalne",62.

Co oznaczają te słowa Penitencjarii i dlaczego taka ocena moralna?

Ponieważ nie ma żadnego sprawiedliwego, moralnie pewnego rozwiązania problemu zamrożonych embrionów, a problem musi być rozwiązany, gdyż embriony nie mogą być trzymane w zamrożeniu w nieskończoność, tym bardziej, że często prawo stanowione wyznacza te granice, można ,pozwolić im umrzeć". Przy takim rozwiązaniu odpowiedzialność moralna nie spada zasadniczo na tę osobę, która taką decyzję podejmuje i ją urzeczywistnia, ale na te osoby, które są odpowiedzialne za wyprodukowanie tych embrionów i za ich zamrożenie.

$\mathrm{Na}$ takie rozwiązanie trzeba spojrzeć również z perspektywy rodziców (zwłaszcza matki) zamrożonych embrionów. Ewidentnie ponoszą oni odpowiedzialność za skorzystanie z niemoralnej biotechnologii i za zamrożenie ich dzieci. Jednakże moralnie słuszne jest pragnienie naprawienia wcześniej popełnionego zła, czyli rozmrożenie embrionu(ów), jego (ich) przyjęcie przez genetyczną matkę i gotowość jego (ich) urodzenia. W praktyce jednak realizacja takiego, moralnie słusznego, postanowienia nie zawsze jest prosta i możliwa. Ocena moralna musi więc uwzględniać konkretne uwarunkowania mające istotne znaczenie dla zakresu odpowiedzialności matki na tym etapie procedury in vitro.

Nade wszystko trzeba mieć na uwadze fakt, że za jednym razem może być rozmrożony najwyżej jeden embrion, wyjątkowo dwa, gdyż - jak wcześniej

${ }^{61}$ JAN PAWEŁ II, Przemówienie do uczestników sympozjum na temat: „Evangelium vitae a prawo" i XI Miedzynarodowego Kolokwium Prawa Kanonicznego (24 maja 1996), AAS 88(1996), 943-944, por. także KongregACJA NAUKI WIARY, Instrukcja „Dignitas personae”, nr 19.

${ }^{6}$ PENITENCJARIA APOSTOLSKA, Odpowiedź na pytanie o rozwiazanie problemu z zamrożonymi embrionami. Prot. N. 502/11, Rzym 28.10.2011, nr 1. 
podkreślono - z medycznego punktu widzenia nie jest wskazane tworzenie ciąży mnogiej. Jednocześnie etyczne postępowanie zdecydowanie wyklucza transferowanie większej ilości embrionów, a następnie pozostawienie w łonie matki tylko jednego, ewentualnie dwóch, które się zagnieździły w śluzówce i dobrze się rozwijają, przy jednoczesnym abortowaniu drugiego lub pozostałych. W praktyce więc, jeżeli pierwszy(sze) embrion(y) przeniesiony(e) do łona matki rozwija(ją) się poprawnie, to następny(e) (wciąż zamrożony/e) musi(muszą) czekać w kolejce do czasu przyjścia na świat poprzedniego (nich), plus okres przerwy po porodzie. Jeżeli kobieta jest zdrowa, ma normalny cykl płodności i nie ma przeciwskazań lekarskich, to kolejny transfer może mieć miejsce w czasie zbliżonym do następnej owulacji ${ }^{63}$. W niektórych przypadkach kolejny transfer praktykuje się po trzymiesięcznej przer$w_{i}{ }^{64}$. Ponadto po udanym transferze i po urodzeniu dziecka, kolejne przeniesienie embrionu do łona matki nie powinno mieć miejsca w czasie karmienia piersią, gdyż w tym czasie ,przeciwwskazane jest przyjmowanie [przez nią] leków hormonalnych niekiedy niezbędnych do stosowania w trakcie przygotowań do transferu, a także z uwagi na wpływ karmienia na prawidłowość cyklu, co się przekłada na skuteczność transferu"65. Natomiast większe przerwy muszą mieć miejsce w przypadku cyklu „sztucznego”, kiedy przez stymulację hormonalną pobudza się macicę do wykształcenia śluzówki. W tym przypadku kolejny transfer nie powinien mieć miejsca wcześniej niż po trzech cyklach przerwy ${ }^{66}$. Nie do wykluczenia jest również możliwość innych komplikacji zdrowotnych, które bez winy matki oddalają w czasie kolejny transfer. Powyższe uwarunkowania zdrowotne i medyczne to jeden z powodów, dlaczego nie można „wymuszać” na matce decyzji o rozmrożeniu

${ }^{63}$ Por. Forum embriologiczne: Na jakim cyklu powinien odbyć się kriotransfer, jeżeli mam skłonności do powstawania torbieli i polipów endometrialnych? Portal Przychodni Leczenia Niepłodności „nOvum”, https://www.novum.com.pl/pl/leczenie-nieplodnosci/forum-embriologiczne/strona/1/\#accordion-faq-111-7250 (dostęp: 24.04.2020); Forum. Odwołano moje drugie podejście do kriotransferu, Portal Przychodni Leczenia Niepłodności „nOvum”, https://www. novum.com.pl/pl/leczenie-nieplodnosci/forum-embriologiczne/strona/1/\#accordion-faq-111-7176 (dostęp: 24.04.2020).

${ }^{64}$ Por. Forum embriologiczne. Ciaża pozamaciczna - po jakim czasie moge podejść znowu do in vitro?, Portal Przychodni Leczenia Niepłodności ,nOvum”, https://www.novum.com.pl/pl/ leczenie-nieplodnosci/forum-embriologiczne/strona/9/\#accordion-faq-111-5590 (dostęp: 24.04. 2020).

${ }^{65}$ Forum embriologiczne. Po jakim czasie od porodu siłami natury można podejść do kriotransferu?, Portal Przychodni Leczenia Niepłodności „nOvum”, https://www.novum.com.pl/p1/lecze nie-nieplodnosci/forum-embriologiczne/strona/3/\#accordion-faq-111-5617 (dostęp: 24.04.2020).

${ }^{66}$ Por. Forum embriologiczne. Kiedy moge mieć nastęnny transfer? Portal Przychodni Leczenia Niepłodności „nOvum”, https://www.novum.com.pl/pl/leczenie-nieplodnosci/forumembriologiczne/ strona/3/\#accordion-faq-111-5448 (dostęp: 24.04.2020). 
i transferze embrionu(ów). Jednocześnie brak takiej decyzji z jej strony nie powoduje zaciaggnięcia przez nią winy moralnej.

Kolejna racja, dla której moralnie dopuszczalna może być zgoda na rozmrożenie embrionów i ich obumarcie, to dostatecznie uzasadnione przewidywanie, że transfer i urodzenie dziecka się nie powiodą. Chodzi tutaj zwłaszcza o sytuację, kiedy prowadzone badania w pewnym momencie odkrywaja u matki nieuleczalną przyczynę uniemożliwiającą donoszenie ciąży. W tej sytuacji, znając ponadto możliwe przeciążenie psychiczne i fizyczne matki (małżonków), można uznać jej (ich) trudną sytuację za zwalniająca z kontynuacji starań o kolejny transfer.

Bliska takiemu stanowi matki jest sytuacja, kiedy ona już kilka razy bezskutecznie poddawała się zabiegowi transferu i w pewnym momencie dochodzi do wniosku, że dalsze wysiłki, czynione w tym kierunku, przekraczają jej możliwości fizyczne i/lub psychiczne. W tym kontekście nie do pominięcia są świadectwa małżeństw, które wielokrotnie próbowały skorzystać z omawianej metody. Kolejne rozczarowania nawarstwiają przeżywane przez nie frustracje, stają się źródłem coraz większego stresu psychicznego i moralnego. W końcu prowadzą do głębokiego kryzysu ich związku, a nawet do jego rozpadu.

Powyższe uwarunkowania i wątpliwości zwalniają matkę (małżonków) z moralnego obowiązku podjęcia starań mających na celu rozmrożenie, przyjęcie i urodzenie jej (ich) embrionów. Zgodnie z zasadami moralnymi, psychiczna czy fizyczna niemożliwość zwalnia człowieka z moralnej odpowiedzialności (stosownie do stopnia świadomości czynu i jego wartości moralnej oraz zgody powiązanej z wolnością działania ${ }^{67}$.

Druga grupę okoliczności, dopuszczających zgodę na rozmrożenie i obumarcie embrionów, Penitencjaria Apostolska wiąże z ich stanem zdrowotnym. Dykasteria wyjaśnia: „Jest moralnie dopuszczalne podjąć próbę prokreacji, przenosząc do macicy matki pozostałe embriony, pod warunkiem, że są one nadal po zamrożeniu biologicznie odpowiednie do transferu, unikając wszelkich form eugenicznej selekcji”" ${ }^{68}$.

Przedstawiony warunek moralnie dopuszczalnej rezygnacji $\mathrm{z}$ transferu domaga się rozpatrzenia kilku możliwych sytuacji. Pierwsza sytuacja dotyczy embrionu, który po rozmrożeniu nie podjął procesów życiowych. Oznacza to, że jest on już obumarły. Jego szczątki doczesne nie mogą być jednak trakto-

${ }^{67}$ Por. JAN PAWEŁ II, Encyklika „Veritatis splendor”, nr 70-72; także JAN PAWEŁ II, Adhortacja apostolska „Reconciliatio et paenitentia”, Rzym 1984, nr 17: „Grzechem śmiertelnym jest ten, który dotyczy materii poważnej i który nadto został popełniony z pełną świadomością i całkowitą zgodą".

${ }^{68}$ Odpowiedź na pytanie o rozwiazanie problemu z zamrożonymi embrionami, $\mathrm{nr} 3$. 
wane jako moralnie obojętny materiał biologiczny. Kościół domaga się: „Zwłoki embrionów [...] powinny być uszanowane tak, jak zwłoki innych istot ludzkich" ${ }^{69}$. Oznacza to, że nie mogą one być w dowolny sposób zutylizowane czy zwyczajnie wyrzucane. Winny one być godnie pochowane na wzór ludzkich płodów. Takie obumarłe embriony mogą być jednak - za zgodą rodziców - przekazane do badań naukowych, jednak z zachowaniem godnego i pełnego szacunku ich traktowania, a pozostałości po badaniu, na ile to możliwe, zebrane i godnie pochowane.

Przytoczony dokument Penitencjarii sugeruje dalej, że rodzice mogą czuć się zwolnieni z dążenia do transferu embrionów, które są obciążone ewidentnymi wadami rozwojowymi uniemożliwiającymi ich implantację i rozwój, to znaczy nie są zdolne do życia. Zgoda na obumarcie takich embrionów nie jest jedynie możliwym postępowaniem z nimi. Za zgodą rodziców mogą być i one przedmiotem medycznego badania, jednak cały czas z pełnym poszanowania ich traktowaniem, wolnym od ryzyka naruszenia ich integralności czy bezpośredniego, tzn. zamierzonego ich uśmiercenia. Dalej, jeżeli byłoby możliwe, należałoby podjąć działania terapeutyczne, w tym także za zgodą rodziców, stosując metody nowatorskie, budzące uzasadnioną nadzieję na pozytywny skutek. Wydaje się jednak, że w tym wymiarze niewiele da się zrobić, gdyż jak na razie przekracza to możliwości technik terapeutycznych. Dotyczy to zwłaszcza terapii genowych, które są obciążone zbyt dużym ryzykiem niemożliwych do naprawienia dziedzicznych zmian w genomie $^{70}$. Kościół jednocześnie potępia prowadzenie na żyjących embrionach doświadczeń w celach nieleczniczych ${ }^{71}$.

Gotowość postępowania o charakterze terapeutycznym ma też swoje granice. Zgodnie $\mathrm{z}$ zasadami etycznymi, należy zrezygnować $\mathrm{z}$ prób leczenia (w praktyce w ogóle ich nie podejmować), które zgodnie z wiedzą i doświadczeniem lekarzy nie mają szans powodzenia. Chodzi tutaj o takie sytuacje i działania, które w praktyce prowadziłyby tylko do wydłużenia procesu obumierania embrionu ${ }^{72}$.

69 „Zwłoki embrionów lub płodów ludzkich, pochodzące z dobrowolnych przerywań ciąży czy też nie, powinny być uszanowane tak jak zwłoki innych istot ludzkich" (KongregaCJA NAUKI WIARY, Instrukcja „Donum vitae”, nr I, 4; także Instrukcja „Dignitas personae”, nr 35).

${ }^{70}$ Por. Kongregacja NAUKI WiARY, Instrukcja „Dignitas personae”, nr 26.

${ }^{71}$ Por. Kongregacja NAUKI WiaRY, Instrukcja „Donum vitae”, nr I, 4; także KongReGACJA NAUKI WIARY, Instrukcja „Dignitas personae”, nr 34.

${ }^{72}$ Chodzi tutaj o rezygnację z tak zwanej „terapii daremnej”: „Od eutanazji należy odróżnić decyzję o rezygnacji z tak zwanej «uporczywej terapii», to znaczy z pewnych zabiegów medycznych, które przestały być adekwatne do realnej sytuacji chorego, ponieważ nie są już współmierne do rezultatów, jakich można by oczekiwać, lub też są zbyt uciążliwe dla samego 
Pomocnym w zrozumieniu takiego rozwiązania może być rozstrzygnięcie kwestii dziecka anencefalicznego. Papieska Rada ds. Duszpasterstwa Służby Zdrowia uczy: „Jeżeli stwierdzi się anencefalię, nie jest dozwolone zastosowanie aborcji. [...] Dzieci te po urodzeniu powinny zostać poddane jedynie zwykłej opiece medycznej, włączając w to opiekę paliatywną, unikając przy

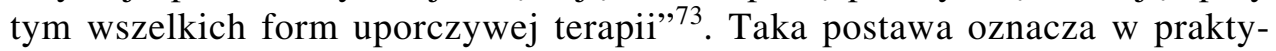
ce pozwolić im godnie umrzeć, co następuje bardzo szybko.

Penitencjaria Apostolska odrzuca jako niemoralne selekcyjne lub eugeniczne traktowanie rozmrożonych embrionów. Nie chodzi tutaj o jakieś oryginalnie nowe zagadnienie bioetyczne. W grę wchodzi tutaj bowiem taka sama praktyka i takie same zasady etyczne, jak w przypadku diagnozy przedimplantacyjnej.

Konsekwentnie nieetyczne jest rozmrożenie i wybór do transferu tylko tych embrionów, które posiadają pożądaną płeć. Podobnie niedopuszczalne jest badanie genetyczne embrionów celem transferowania tylko uznanych za wolne od wad wrodzonych przy jednoczesnym odrzuceniu obciążonych wadami lub przynajmniej niepewnych. Z moralnego punktu widzenia za zgodą rodziców możliwa jest natomiast taka diagnoza, jeżeli miałaby ona na celu podjęcie praktycznie możliwego leczenia embrionów obciążonych wadami, bez nieproporcjonalnie wielkiego zagrożenia dla jego życia i integralności ${ }^{74}$. Magisterium podsumowuje selekcję eugeniczną: „Tego rodzaju mentalność urąga ludzkiej godności i jest w najwyższym stopniu naganna, ponieważ rości sobie prawo do mierzenia wartości ludzkiego życia wyłącznie według kryteriów normalności i zdrowia fizycznego [...]. Takie postępowanie faktycznie ma na celu jakościową selekcję embrionów i w konsekwencji ich niszczenie, co jawi się jako wczesne działanie aborcyjne"75. W powyższym kontekście warto

chorego i dla jego rodziny. W takich sytuacjach, gdy śmierć jest bliska i nieuchronna, można w zgodzie z sumieniem «zrezygnować z zabiegów, które spowodowałyby jedynie nietrwałe i bolesne przedłużenie życia, nie należy jednak przerywać normalnych terapii, jakich wymaga chory w takich przypadkach». Istnieje oczywiście powinność moralna leczenia się i poddania się leczeniu, ale taką powinność trzeba określać w konkretnych sytuacjach: należy mianowicie ocenić, czy stosowane środki lecznicze są obiektywnie proporcjonalne do przewidywanej poprawy zdrowia. Rezygnacja ze środków nadzwyczajnych i przesadnych nie jest równoznaczna z samobójstwem lub eutanazją; wyraża raczej akceptację ludzkiej kondycji w obliczu śmierci” (JAN PAWE€ II, Encyklika „Evangelium vitae”, nr 65).

${ }^{73}$ Nowa Karta Pracowników Stużby Zdrowia, nr 58.

${ }^{74}$ Por. Kongregacja NAUKI WIARY, Instrukcja „Donum vitae”, nr I, 2; PAPIESKA RADA DS. DusZPasterstwa SŁUŻBy Zdrowia, Nowa Karta Pracowników Stużby Zdrowia, nr 36.

75 Papieska RAda ds. DusZPasterstwa SŁuŻBy Zdrowia, Nowa Karta Pracowników Stużby Zdrowia, nr 36; także KongregaCJA NAUKI WIARY, Instrukcja „Dignitas personae”, nr 22. 
odnotować, że niektóre embriony, uznane za obciążone wadami wrodzonymi, rozwijają się poprawnie, gdyż są one zdolne do naprawienia niewielkich błędów, z kolei inne przeważnie obumierają. W końcu u jeszcze innych, u których badanie nie wykazuje żadnych błędów, wady wrodzone ujawniają się dopiero na dalszych etapach życia, już po urodzeniu.

Procedura sztucznej prokreacji i związane z nią zamrażanie nadliczbowych embrionów niesie ze sobą poważne wyzwania moralne. Praktyki te są źródłem istotnych zagrożeń dla ich godności osobowej, dla ich życia i dla integralności ich delikatnej struktury biologicznej. Zło moralne takiego postępowania pomnaża brak sprawiedliwego rozwiązania problemu porzucanych embrionów. Stąd wołanie Kościoła, aby kliniki praktykujące in vitro powstrzymały się od stosowania tej technologii.

Jedynym sprawiedliwym rozwiązaniem problemu zamrożonych embrionów jest stopniowe ich rozmrażanie i przyjęcie przez genetyczną matkę. Jednak możliwości takiego rozwiązania są bardzo ograniczone, a niekiedy wprost niemożliwe. Stąd, kiedy konieczne jest zakończenie zamrożenia, jedynym możliwym rozwiązaniem jest pozwolenie embrionom na ich obumarcie. Prawda ta o prokreacji wspomaganej, często bagatelizowana przez pracowników klinik wspomaganego rozrodu i przez prawo stanowione, odsłania ogrom zła moralnego i odpowiedzialność osób korzystających z tej biotechnologii.

Powyższe uwagi mają istotne znaczenie dla posługi duszpasterskiej. Sugerują one, że jakkolwiek można zachęcać matkę (rodziców) do stopniowego rozmrażania i urodzenia ich dzieci, to jednak nie można ich do tego przymuszać. Nie można też uzależnić udzielenia rozgrzeszenia w Sakramencie Pojednania i Pokuty od obietnicy transferu zamrożonych embrionów. W partykularnych przypadkach takie zobowiązanie może przekraczać obiektywne możliwości matki.

\section{BIBLIOGRAFIA}

\section{I. ŹRÓDŁA KOŚCIELNE}

Enchiridion symbolorum definiotionum et declarationum de rebus fidei et morum, red. H. Denzinger, Bologna 1995.

LEON X, Bulla „Apostolici regiminis: De anima humana doctrina contra Neo-Aristotelicos”, Rzym 1513, w: Enchiridion symbolorum definiotionum et declarationum de rebus fidei et morum, red. H. Denzinger, Bologna 1995, nr 1440-1441. 
ALEKSANDER VII, Breve „Sollicitudo omnium ecclesiarum: De immaculata conceptione B. Mariae Virginis", Rzym 1661, w: Enchiridion symbolorum definiotionum et declarationum de rebus fidei et morum, red. H. Denzinger, Bologna 1995, nr 2015-2017.

PIUS XII, Encyklika „Humani generis”, Rzym 1950, AAS 42(1950)17, 561-578.

PIUS XII, Przemówienie do Uczestników IV Międzynarodowego Kongresu Lekarzy Katolickich (29.09.1949), AAS 41(1949), 557-561.

PIUS XII, Przemówienie do Uczestników Kongresu Katolickiej Unii Położnych Włoskich (29.10. 1951), AAS 43(1951), 838-844.

PIUS XII, Przemówienie do Uczestników II Światowego Kongresu na temat płodności i bezpłodności (19.05.1956), AAS 48(1956), 467-474.

PIUS XII, Przemówienie do Uczestników VII Międzynarodowego Kongresu Światowej Organizacji Hematologii (12.09.1958), AAS 50(1958), 732-740.

JAN XXIII, Encyklika „Mater et Magistra”, Rzym 1961.

JAN PAWEŁ II, Encyklika „Veritatis splendor”, Rzym 1993.

JAN PAWEŁ II, Encyklika „Evangelium vitae”, Rzym 1995.

JAN PAWEE II, Adhortacja apostolska „Reconciliatio et paenitentia”, Rzym 1984.

JAN PAWEŁ II, Przemówienie do uczestników sympozjum na temat „Evangelium vitae” a prawo i na XI Międzynarodowym Kolokwium Prawa Kanonicznego, „L'Osservatore Romano” (PL) 1996, nr 9, 44; AAS 88(1996), 943-944.

BENEDYKT XVI, Encyklika „Caritas in veritate”, Rzym 2009.

FranciszeK, Lettera al Mons. Rino Fisichella Presidente del Pontificio Consiglio per la Promozione della Nuova Evangelizzazione con la quale si concede l'indulgenza in occasione del giubileo straordinario della misericordia, Rzym 2015, http://w2.vatican.va/content/ francesco/pl/letters/2015/documents/papa-francesco_20150901_lettera-indulgenza-giubileomisericordia.html (dostęp: 24.04.2020).

FRANCISZEK, List apostolski „Misericordia et misera”, Rzym 2016.

KongregaCJa NAUKI Wiary, Deklaracja „De abortu procurato”, Rzym 1974.

KONGREGACJA NAUKI WIARY, Instrukcja o szacunku dla rodzącego się życia ludzkiego i o godności jego przekazywania „Donum vitae”, Rzym 1987.

KONGREGACJA NAUKI WIARY, Instrukcja „Dignitas personae” dotycząca niektórych problemów bioetycznych, Rzym 2008.

SACRUM OfFICIUM, Fecondazione artificiale, Roma 1897, ASS 29(1896-1897), 704; Denz 3323;

PAPIESKA RADA DS. RoDZINY, Rodzina i prokreacja ludzka, Rzym 2006.

PAPIESKa RADA DS. DUSZPASTERSTWa SŁUŻY ZDROwia, Nowa karta pracowników służby zdrowia, Rzym 2016.

PAPIESKa AKADEMIA „Pro VitA”, Refleksje na temat klonowania, Rzym 1997.

PAPIESKA AKADEMIA „PRO ViTA”, Ludzki embrion w fazie preimplantacyjnej. Aspekty naukowe i refleksje bioetyczne, Rzym 2006.

Pontificia COMmissio CODICI LURIS CANONICI AUTHENTICE INTERPRETANDO, Interpretatio authentica Can. 1398, AAS, 80(1988), 1818-1819; także http://www.delegumtextibus.va/con tent/testilegisla tivi/it/attivita/interpretazioni/can1398.html (dostęp: 27.10.2018).

Pontificium Consilium De Legum TeXtibus, [List] Resp. Prot. N. 15208/2015, 24 listopada 2015, http://www.delegumtextibus.va/content/dam/testilegislativi/risposte-particolari/cic/Circa $\% 201 \mathrm{a} \% 20$ facolt $\% \mathrm{C} 3 \%$ A0\%20di $\% 20$ assolvere $\% 20$ dal $\% 20$ peccato $\% 20$ di $\% 20$ aborto $\% 20 \mathrm{c}$ oncessa\%20a\%20tutti\%20sacerdoti\%20per\%201\%27 Anno \%20Giubilare.pdf (dostęp: 28.04. 2020).

PenitenCJARIa Apostolska, Odpowiedź na pytanie o rozwiązanie problemu z zamrożonymi embrionami. Prot. N. 502/11, Rzym 28.10.2011.

Katechizm Kościoła katolickiego, wyd. 2, Poznań 2002. 


\section{LITERATURA TEOLOGICZNOMORALNA I BIOETYCZNA}

BIESAga T., Bioetyka, w: Encyklopedia bioetyki. Personalizm chrześcijański. Głos Kościoła. Radom 2005, s. 54-62.

Beauchamp T.L., ChiLdress J.F., Zasady etyki medycznej, Warszawa 1996.

CHIOdI M., Modelli teoretici in bioetica, Milano 2005.

Dogmatyka, t. 6, red. E. Adamiak, A. Czaja, J. Majewski, Warszawa 2005-2007.

Encyklopedia bioetyki, Personalizm chrześcijański. Głos Kościoła. Radom 2005.

PASCUAL R., Modelli di bioetica, Roma 2007.

RosIK S., Techniki manipulacyjne w aspekcie wymagań moralnych, „Roczniki TeologicznoKanoniczne" 25(1978), z. 3, s. 23-38.

Sgreccia S., Manuale di bioetica, t. 1: Fondamenti e etica biomedica, wyd. 4, Milano 2007, s. 55-99.

Wencel K.T., Traktat o człowieku, w: Dogmatyka, t. 5, red. E. Adamiak, A. Czaja, J. Majewski, Warszawa 2007, s. 15-212.

WRÓBEL J., Antropologiczne implikacje sztucznej prokreacji, „Roczniki Teologiczne” 62(2015), z. 3, s. 77-100.

WróBEL J., Człowiek i medycyna. Teologicznomoralne podstawy ingerencji medycznych, Kraków 1999.

WróBel J., Poczęcie człowieka i status jednokomórkowej ludzkiej zygoty z perspektywy bioetyki katolickiej, „Roczniki Teologiczne” 64(2017), z. 3, s. 79-92.

WRÓBEL J., Prokreacja technicyzowana - wyzwania etyczne, „Roczniki Teologii Moralnej” 56(2009) 3, s. 183-202.

\section{LITERATURA BIOLOGICZNA I MEDYCZNA}

BARTEl H., Embriologia, wyd. 4, Warszawa 2007.

BISZEWSKA-MiĘTKA J., Mrożenie zarodków - sposób na odłożenie macierzyństwa w czasie? http://www.edziecko.pl/przed_ciaza/1,8784115355849,Mrozenie_zarodkow_sposob_na_odlo zenie_macierzynstwa.html (dostęp: 27.10.2018).

Check J.H., Summers-Chase D., Yuan W., Swenson K., Horwath B Camden D., Length of time of embryo storage does not negatively influence pregnancy rates after thawing and transfer, „Clinical and Experimental Obstetrics and Gynecology” 37(2010), nr 3, s. 185-186.

De Mouzon J., Goossens V., Bhattacharya S., Castilla J.A., Ferraretti A.P., Korsak V., KuPKa M., NYGRen K.G., NyboE ANDERSEN A., Assisted reproductive technology in Europe, 2006: results generated from European registers by ESHRE [European Society of Human Reproduction and Embryology], „Human Reproduction” 25(2010), nr 8, s. 1851-1862.

Dowling-Lacey D., Mayer J.F., Jones E., Bocca S., StadtMauer L., Oehninger S., Live birth from a frozenBthawed pronuclear stage embryo almost 20 years after its cryopreservation, „Fertility and Sterility” 95(2011), nr 3, 1120.e1-1120.e3.

El Mokhallalati Y., Van EeKelen R., Bhattacharya S., McLernon D.J., Treatmentindependent live birth after in-vitro fertilisation: a retrospective cohort study of 1133 women, „Human Reproduction” 34(2019), nr 8, s. 1470-1478.

LEETON J., The early history of IVF in Australia and its contribution to the World (19701990). „Australian and New Zealand Journal of Obstetrics and Gynaecology” 44(2004), nr 6, s. 495-501. 
Midro A., Zagrożenia genetycznego dziedzictwa u dzieci poczętych in vitro, w: Wobec in vitro. Genetyczne, moralne, filozoficzne, teologiczne i prawne aspekty zapłodnienia pozaustrojowego, red. J. Grzybowski, F. Longchamps de Bérier, Kielce 2017, s. 149-171.

NiwiŃSKA A., Przegląd metod kriokonserwacji pod kątem techniki witryfikacyjnej, „Życie Weterynaryjne" 2016, $\mathrm{nr}$ 7(91), s. 505-508.

Nyboe Andersen A., Goossens V., Ferraretti A.P., Bhattacharya S., Felberbaum R., De Mouzon J., Nygren K.G., Assisted reproductive technology in Europe, 2004: results generated from European registers by ESHRE [European Society of Human Reproduction and Embryology], „Human Reproduction” 23(2008), nr 4, s. 756-771.

Nyboe Andersen A., Goossens V., Bhattacharya S., Ferraretti A.P., KupKa M.S., De Mouzon J., NyGREn K.G., Assisted reproductive technology and intrauterine inseminations in Europe, 2005: results generated from European registers by ESHRE, „Human Reproduction" 24(2009), nr 1, s. 1-21.

Ontogeneza, w: Wielka encyklopedia medyczna, red. E. Cravetto, t. 14, Warszawa, 2011, s. 248.

PAPIS K., LEWANDOWSKi P., Wolski J.K., KozIOŁ K., Dzieci urodzone z zarodków przechowywanych w stanie zamrożenia przez 10 lat. Analiza 5 przypadków, „Ginekologia Polska” 2013, nr 11(84), s. 970-973.

PaWelczyk L., Serdyńska M., Zapłodnienie, w: Położnictwo i ginekologia, t. 1, red. G.H. Bręborowicz, Warszawa 2008, s. 1-6.

Polge C., Smith A.U., PARKes A.S., Revival of spermatozoa after vitrification and dehydration at low temperatures, „Nature” 164(1949), s. 666-667.

Położnictwo i ginekologia, 2 t., red. G.H. Bręborowicz, Warszawa 2008.

PSTRĄG M., Z zarodka zamrożonego przez 16 lat urodziło się zdrowe dziecko! https://mamo toja.pl/mrozenie-zarodkow-do-in-vitro-to-bezpieczne-przez-dlugie-lata,in-vitro-artykul,22 28łr1p1.html (dostęp: 27.04.2020).

Rall W.R., Ernest John Christopher Polge FRS (1926-2006), „Cryobiology” 54(2007), nr 3, S. 241-242.

Riggs R., Mayer J., Dowling-Lacey D., Chi T.-F., Jones E., Oehninger S., Does storage time influence post thaw survival and pregnancy outcome? An analysis of 11,768 cryopreserved human embryos, „Fertility and Sterility” 93(2010), nr 1, s. 109-115.

SOCIETY FOR ASSISTED RePRODUCTIVE TECHNOLOGY, IVF Success. 2016 Preliminary National Data, https://www.sartcorsonline.com/rptCSR_PublicMultYear.aspx?reportingYear=2016 \#help (dostęp: 27.10.2018).

WASILEWSKI T., Procedura in vitro - technika i konsekwencje, w: Wobec in vitro. Genetyczne, moralne, filozoficzne, teologiczne i prawne aspekty zapłodnienia pozaustrojowego, red. J. Grzybowski, F. Longchamps de Bérier, Kielce 2017, s. 17-45.

Wielka encyklopedia medyczna, red. E. Cravetto, 23 t., Warszawa 2011.

\section{OPRACOWANIA SPECJALISTÓW Z KLINIK LECZENIA NIEPŁODNOŚCI}

Forum embriologiczne, Ciąża pozamaciczna - po jakim czasie mogę podejść znowu do in vitro?, Portal Przychodni Leczenia Niepłodności „nOvum”, https://www.novum.com.pl/pl/ leczenie-nieplodnosci/forum-embriologiczne/strona/9/\#accordion-faq-111-5590 (dostęp: 24.04.2020).

Forum embriologiczne, Co oznacza opis zarodka cl5.3 zamrożonego w 2 dniu, jaka jest jego jakość? Portal Kliniki ,nOvum”, https://www.novum.com.pl/pl/leczenie-nieplodnosci/forumembriologiczne/strona/0/\#accordion-faq-111-7554 (dostęp: 24.04.2020). 
Forum embriologiczne, Czy mam szansę na pozytywny crio transfer z zamrożonych 3-dniowych zarodków: cl 9.3 i cl 10.3?, Portal Kliniki „nOvum”, https://www.novum.com.pl/pl/le czenie-nieplodnosci/forum-embriologiczne/strona/0/\#accordion-faq-111-7526(dostęp:24.04. 2020).

Forum embriologiczne, Ile i które zarodki wybrać do kriotransferu?, Portal Kliniki nOvum, https://www.novum.com.pl/pl/leczenie-nieplodnosci/forum-embriologiczne/pytanie/512/ (dostęp: 19.04.2020).

Forum embriologiczne, Kiedy mogę mieć następny transfer? Portal Przychodni Leczenia Niepłodności „nOvum”, https://www.novum.com.pl/pl/leczenie-nieplodnosci/forum-embrio lo giczne/strona/3/\#accordion-faq-111-5448 (dostęp: 24.04.2020).

Forum embriologiczne, Na jakim cyklu powinien odbyć się kriotransfer, jeżeli mam skłonności do powstawania torbieli i polipów endometrialnych? Portal Przychodni Leczenia Niepłodności ,nOvum”, https://www.novum.com.pl/pl/leczenie-nieplodnosci/forum-embriologiczne/ strona/1/\#accordion-faq-111-7250 (dostęp: 24.04.2020).

Forum embriologiczne, Od czego zależy, na jakim etapie zarodek zostaje zamrożony, Portal Kliniki,,nOvum”,https://www.novum.com.pl/pl/leczenie-nieplodnosci/forum-embriologiczne/ strona/1/\#accordion-faq-111-7253 (dostęp: 24.04.2020).

Forum embriologiczne, Odwołano moje drugie podejście do kriotransferu, Portal Przychodni Leczenia Niepłodności,,nOvum”, https://www.novum.com.pl/pl/leczenie-nieplodnosci/forum -embriologiczne/strona/1/\#accordion-faq-111-7176 (dostęp: 24.04.2020).

Forum embriologiczne, Po jakim czasie od porodu siłami natury można podejść do kriotransferu? Portal Przychodni Leczenia Niepłodności „nOvum”, https://www.novum.com.pl/pl/lecze nienieplodnosci/forum-embriologiczne/strona/3/\#accordion-faq-111-5617 (dostęp: 24.04. 2020).

In vitro - IVF - Zapłodnienie pozaustrojowe, INVICTA. Klinika Leczenia Niepłodności, https: //www.klinikainvicta.pl/leczenie-nieplodnosci/metody-leczenia/zaplodnienie-in-vitro/(dostęp: 09.05.2020).

Kriokonserwacja komórek jajowych i zarodków, GMW - Embrio, http://invitrogmw.pl/nieplod nosc-2/pracownia-embriologiczna/kriokonserwacja-zarodkow/ (dostęp: 27.10.2018).

Mrożenie zarodków - kriokonserwacja, INVICTA. Klinika Leczenia Niepłodności, https:// www.klinikainvicta.pl/nieplodnosc-faq/mrozenie-zarodkow-kriokonserwacja/ (dostęp: 19.04.2020).

Transfer zarodków, PARENS. Centrum Leczenia Niepłodności, http://parens.pl/jestem-w-trakcie-leczenia/transfer-zarodkow/ (dostęp: 19.04.2020).

Witryfikacja zarodków i oocytów, Gyncentrum. Klinika Leczenia Niepłodności i Diagnostyki Prenatalnej, https://www.gyncentrum.pl/witryfikacja-zarodkow-i-oocytow (dostęp: 27.10. 2018).

WoJTASIK B., Witryfikacja, czyli szybkie mrożenie zarodków i gamet, InviMed. Kliniki leczenia niepłodności, https://www.invimed.pl/witryfikacja-czyli-mrozenie-zarodkow-i-gamet (dostęp: 19.04.2020).

Mrożenie zarodków - kriokonserwacja, INVICTA. Klinika Leczenia Niepłodności, https://www.k linikainvicta.pl/nieplodnosc-faq/mrozenie-zarodkow-kriokonserwacja/ (dostęp: 19.04. 2020).

Witryfikacja, czyli szybkie mrożenie zarodków i gamet, InviMed. Kliniki leczenia niepłodności, https://www.invimed.pl/witryfikacja-czyli-mrozenie-zarodkow-i-gamet (dostęp: 19.04.2020).

Witryfikacja zarodków i oocytów, Gyncentrum. Klinika leczenia niepłodności i diagnostyki prenatalnej, https://www.gyncentrum.pl/witryfikacja-zarodkow-i-oocytow (dostęp: 27.10. 2018).

Wykrycie wad genetycznych podczas in vitro. Gyncentrum. Klinika leczenia niepłodności i diagnostyki prenatalnej, https://www.gyncentrum.pl/blog/pl/wykrycie-wad-genetycznychpodczas-in-vitro (dostęp: 17.04.2020).

Zespół Hiperstymulacji, Klinika Leczenia Niepłodności Gameta, https://gameta.pl/blog/zespolhiperstymulacji/ (dostęp,17.04.2020). 


\title{
BIOETYCZNY I TEOLOGICZNOMORALNY \\ WYMIAR ZAMRAŻANIA LUDZKICH EMBRIONÓW
}

\begin{abstract}
STRESZCZENIE
Artykuł jest poświęcony problematyce kriokonserwacji ludzkich embrionów. Stosowanie tej techniki pozostaje w ścisłym związku z prokreacją wspomaganą. Stwarzane celem zwiększenia skuteczności procedury in vitro nadliczbowe embriony zostają zamrożone, aby następnie można było je wykorzystać w kolejnych próbach transferu. Autor przedstawia techniczny wymiar zamrażania i ryzyko z nim związane. W ostatniej części Autor analizuje wymiar etyczny tych technik. Podkreśla, że chociaż sama prokreacja wspomagana jest niemoralna, to jednak moralnie słuszne jest dążenie do naprawienia tego zła przez matkę, która jest gotowa przyjąc do swojego łona stopniowo rozmrażane embriony. Dobrym rozwiązaniem wydaje się być adopcja porzuconych embrionów. Takiego rozwiązania nie da się jednak usprawiedliwić z punktu widzenia etycznego. Jeżeli rozmrożenie zostaje wymuszone przez prawo lub wymówienie umowy przez klinikę przechowywującą te embriony, możliwa jest zgoda na ich obumarcie. $\mathrm{Z}$ obowiązku transferu zwalnia również stan zdrowotny embrionów uniemożliwiający ich rozwój. Ponadto niemoralna jest selekcja eugeniczna embrionów oraz transfer wyłącznie tych embrionów, które mają pożądane cechy fenotypowe czy płeć.
\end{abstract}

Słowa kluczowe: zamrażanie embrionów; ART; prokreacja wspomagana. 